\title{
Fluid-mediated mass transfer from a paleosubduction channel to its mantle wedge: Evidence from jadeitite and related rocks from the Guatemala Suture Zone
}

\author{
George E. Harlow ${ }^{1}$, Kennet E. Flores ${ }^{2,1}$, and Horst R. Marschall ${ }^{3,1}$ \\ ${ }^{1}$ Department of Earth and Planetary Sciences, American Museum of Natural History, New York, \\ NY, 10024-5192 United States \\ ${ }^{2}$ Department of Earth and Environmental Sciences, Brooklyn College, CUNY, Brooklyn, NY \\ 11210, United States (keflores@ brooklyn.cuny.edu) \\ ${ }^{3}$ Woods Hole Oceanographic Institution, Woods Hole, MA 02543, United States \\ (hmarschall@whoi.edu) \\ Corresponding author: George Harlow (gharlow@amnh.org)
}




\begin{abstract}
Jadeitites in serpentinite mélanges are the product of crystallization from and/or metasomatism by aqueous fluids that transfer components from and within a subduction channel- the slabmantle interaction volume - into discrete rock units, most commonly found within the serpentinized or serpentinizing portion of the channel or the overlying mantle rocks at high pressure ( 1 to >2 GPa). Two serpentinite mélanges on either side of the Motagua fault system (MFS) of the Guatemala Suture Zone contain evidence of this process. Whole rock compositional analyses are reported here from 86 samples including jadeitites and the related rocks: omphacitites, albitites and mica rocks. The predominance of a single phase in most of these rocks is reflected in the major element compositions and aspects of the trace elements, such as $\mathrm{REE}$ abundances tracking $\mathrm{Ca}$ in clinopyroxene. Relative to N-MORB all samples show relative enrichments in the high field strength elements (HFSE) Hf, Zr, U, Th, and the LILE Ba and $\mathrm{Cs}$, contrasted by depletions in $\mathrm{K}$ and in some cases $\mathrm{Pb}$ or Sr. Most jadeitites are also depleted in the highly compatible elements $\mathrm{Cr}, \mathrm{Sc}$ and $\mathrm{Ni}$ despite their occurrence in serpentinite mélange; however, some omphacitite samples show the opposite. Trace elements in these jadeitite samples show a strong similarity with GLOSS (globally subducted oceanic sediment) and other terrigenous sediments in terms of their trace-element patterns, but are offset to lower abundances. Jadeitites thus incorporate a strong trace-element signature derived from sediments mixed with that from fluid derived from altered oceanic crust. Enrichment in the HFSE argues for mobility of these elements in aqueous fluids at high P/T conditions in the subduction channel and a remarkable lack of fractionation that might otherwise be expected from dissolution and fluid transport.
\end{abstract}

\title{
Keywords:
}

Jadeitite, omphacitite, albitite, Guatemala, fluid transport 


\section{Introduction}

Jadeitite is a rock composed principally of jadeitic pyroxene that occurs as veins in subduction-zone-related serpentinite and tectonic blocks in serpentinite-matrix mélange associated with blocks of eclogite, blueschist, and other lithologies with high-pressure/lowtemperature (HP-LT) affinity. The phase stability of jadeite and lithologic context indicate formation during subduction. Thus, interest in jadeitite has peaked because of its context of formation, new discoveries and ensuing research. Studies of jadeitite, as reported in recent reviews (e.g., Tsujimori and Harlow, 2012; Harlow et al., 2014; Harlow et al., 2015) support models of formation of jadeitite by two different processes: (i) direct primary crystallization (Ptype of Tsujimori and Harlow, 2012) from a hydrous fluid in the channel (or mixed volume) between the uppermost part of the subducting slab and lowermost part of the mantle wedge ,such as in fractures/veins in metabasite, or above the channel in veins and fractures within the serpentinizing ultramafic (e.g., Yui et al., 2010, Harlow et al., 2011; Schertl et al. 2012) and (ii) metasomatic replacement (R-type) of mafic to felsic protoliths somewhere in the channel or in the incipient formation of serpentinite mélange (e.g., Compagnoni et al., 2012, Shigeno et al., 2012a). In reality, only examination of individual samples and their characteristics (rhythmic zoning and core-cluster fluid inclusions in jadeite, etc. versus clear pseudomorphism or mineral relics of a protolith) yield an interpretation of a sample, and perhaps an entire occurrence, being of P- or R-type. Chances are that most occurrences involve some combination of these two processes, but we can only go by the observations. In either case, jadeitite records mass transfers and interactions by fluid derived from the subducting slab into the transitional mélange and overlying mantle wedge. In addition, how the region of interest - the subduction channel with its fragments of subducted material developing into mélange with an altered ultramafic boundary of the mantle wedge (e.g., Gerya et al., 2002) - is constrained varies between jadeitite occurrences 
and is still a major subject of discussion that will not be resolved here, except to note that examples of or evidence for metasedimentary rocks in the serpentinite mélanges of Guatemala are almost nonexistent.

A key feature of many jadeitites, particularly those from Guatemala and Myanmar, is the lack of free silica, when most interpretations for solute source from sediments and fluid transport, as discussed below, include silica saturation. The context of jadeitite in serpentinite has been the key to interpretations: the reaction of peridotite to serpentinite acts as a sponge for both silica and $\mathrm{H}_{2} \mathrm{O}$, so that fluids entering ultramafic rocks in the subduction environment will crystallize jadeite in lieu of jadeite plus quartz or albite, depending on pressure (see Harlow et al. 2015). Likewise, the presence of late-stage albitites in both Guatemala and Myanmar potentially attests to the limited buffering capacity of an ultramafic host upon silica activity with reaction progress. Finally, the fact that dating of zircon, shown to be of hydrothermal origin, from jadeitite yielded older ages than eclogite metamorphic ages strongly suggests that these jadeitites reside in a non-subducting portion of the channel or the mantle wedge itself (Tsujimori and Harlow, 2012; Flores et al., 2013).

In addition to jadeitite, rocks that are closely associated in many occurrences include omphacitite, albitite, and mica-rich rock. They appear to have a similar but less well studied origin. In addition to saturation of either jadeitic pyroxene or albite (sodium aluminosilicates), the rocks have been shown to be enriched in fluid-mobile elements, such as the large-ion lithophile elements (LILE) Cs, Rb, Ba, as well as Li (e.g., Simons et al., 2010; Sorensen et al., 2006). Likewise, some rocks show a geochemical interaction with altering peridotite with enriched Cr and Ni (ibid, Sorensen et al., 2010; Harlow et al., 2011). Moreover, studies have also focused on trace and rare-earth elemental abundance to determine whether jadeitites from 
specific occurrences are of P- or R-type (e.g., Shigeno et al., 2012a) as well as to gain insight into the signature of the fluid, such as what mixture of sediment, altered oceanic crust (AOC), and serpentinite is sampled (Sorensen et al., 2006; Simons et al., 2010). Finally, in a study of a jadeitite - serpentinite contact in Guatemala, Sorensen et al. (2010) noted a conspicuous elevation in $\mathrm{Zr}, \mathrm{Hf}, \mathrm{U}$ and $\mathrm{Pb}$ in an albitite boundary layer that could not be derived from either jadeitite or serpentinite and suggests enhanced fluid mobility of these elements distinct from the precursor jadeitite forming event. Consequently, in the process of studying the extensive distribution of jadeitite and related rocks in Guatemala, we have undertaken whole-rock geochemical analysis of a large number of samples to permit a comprehensive overview of compositional variation over extensive distances and time.

In Guatemala, jadeitite occurs as blocks in serpentinite-matrix mélange in distinct settings on opposite sides of the Motagua fault, the current North American - Caribbean plate boundary. Jadeitites north of the fault are found in slices of mélange from Saltán, Baja Verapaz to Panaluya (near the town of Río Hondo), Zacapa and near Rosario, Izabal, an E-W distance of $230 \mathrm{~km}$ (Fig. 1: Harlow, 1994; Harlow et al., 2011). Jadeitites south of the Motagua fault are found in three mélange slices restricted to a much smaller areal extent of perhaps $14 \mathrm{~km}$. Moreover, the two distributions are interpreted as of different origin in terms of age and tectonic setting, as described below. Consequently, a study of whole rock compositions offers a potential insight to both a large extent of geographic distribution, which might reflect lateral variations along a subduction system, and of different subduction zone settings as represented by the two different belts. 


\section{Geological Setting}

The Guatemala Suture Zone (GSZ) is the fault-bound region in central Guatemala that contains the present North American-Caribbean plate boundary (Flores et al., 2013 and references therein). This major composite geotectonic unit contains a variety of ophiolites (e.g., Juan de Paz), serpentinite mélanges, mixed metavolcanic-metasedimentary sequences, highgrade schists, gneisses, marbles, and metagranites (e.g., Chuacús complex to the north and Las Ovejas complex to the south) and rare low-grade metasediments thrusted north and south of the active Motagua fault system (MFS, see Fig. 1).

North of the MFS, serpentinite mélange (grouped as the North Motagua Mélange unit NMM) hosts blocks of a variety of metabasites including garnet amphibolite, garnet blueschist, and retrograde clinozoisite-eclogite, and jadeitite, albitite, mica rock, and omphacite-taramite rock (Harlow, 1994, Harlow et al., 2011; Bonnet et al., 2014; Flores et al., 2014). These rocks span a wide range of conditions, from greenschist-blueschist at lower $P\left(200-400{ }^{\circ} \mathrm{C}\right.$ at $\left.\leq 1 \mathrm{GPa}\right)$ to moderate LT eclogite facies of $620^{\circ} \mathrm{C}$ at $\sim 1.7 \mathrm{GPa}$; (Harlow et al., 2008; Brueckner et al., 2009; Bonnet et al., 2014). In contrast, south of the fault, the South Motagua Mélange (SMM) unit includes lawsonite eclogite, glaucophane-bearing metabasites, and jadeitite blocks in serpentinite matrix that record peak $P T$ conditions among the coldest and wettest deep subduction trajectories on Earth, to $\sim 2.6 \mathrm{GPa}$ and only $\sim 470{ }^{\circ} \mathrm{C}$ (Tsujimori et al., 2006a,b) or 2.5GPa and $520^{\circ} \mathrm{C}$ (Endo et al., 2012). A block of epidote amphibolite was found near La Ceiba (Harlow et al. 2011), which may suggest some higher T sampling within the SMM.

Compounding the differences, Harlow et al., (2004a) reported disparate ${ }^{40} \mathrm{Ar} /{ }^{39} \mathrm{Ar}$ ages on the mica and amphibole from these HP-LT rocks: north of the fault ages range between 77 and 65 Ma, whereas rocks south of the fault yield ages of 125-116 Ma. Subsequent determinations of five Sm-Nd mineral isochrons from eclogites both north and south of the fault have yielded ages 
of 144-126 Ma (Brueckner et al., 2009). Recent U-Pb age determinations from zircon in jadeitite and related mica-albite rocks yield ages of 98-80 Ma north of the MFS and 158-130 Ma south of the MFS (Fu et al., 2010; Yui et al., 2010, 2012; Flores et al., 2013). These dates are 10-30 Ma older than the exhumation dates $\left({ }^{40} \mathrm{Ar} /{ }^{39} \mathrm{Ar}\right.$ results) and the peak metamorphic dates south of the MFS and are interpreted by Flores et al. (2013) as a record of pre-exhumation subduction, rather than an inherited protolith age (Fu et al., 2010) (the older eclogite Sm-Nd mineral isochrons north of the MFS require a further complication to the tectonic interpretation which has yet to be hypothesized). Consequently, the discrepant ages are further evidence that the jadeitites from opposite sides of the MFS record different tectonic events and, likely, different subduction system, so the whole rock compositions should reflect somewhat different conditions and sourcing environments.

\section{Sample descriptions}

Rock types in this study include jadeitite, omphacitite, albitite, phengite mica rocks, and cross-over lithologies like jadeitite-omphacitites and albite-mica rocks. Samples have been collected over 22 years from 11 expeditions to the GSZ. Eighty six samples were selected for whole rock analysis; they were considered to span the above lithologies and the regional distributions. These samples are listed in Table 1, with a complete presentation of data in Appendix A. A brief description of rock types and geographic groupings follows; a more complete description, particularly of the jadeitites can be found in Harlow et al. (2011) and Harlow (1994). Abbreviations of mineral phases are after Whitney and Evans (2010) unless otherwise introduced in the text. 


\subsection{North of the MFS}

Distributions of jadeitite, albitite, albite-mica rock, phengite mica rock and omphacitite typically occur as fields up to $100 \mathrm{~m}$ in maximum dimension within serpentinite matrix containing mostly small blocks of the various lithologies (jadeitite, albitite, mica albite rock, etc.) as well as taramite omphacite rocks, chloritite and rarely garnet metabasite (see Harlow et al., 2011). These distributions appear to lie on distinct fault segments or along boundaries with the Chuacús complex. Most of the jadeitite is massive and whitish to pale gray or pale green and commonly with transecting veins of coarser jadeitite or albitite-like alteration. Blocks of whiteto-mauve jadeitite have been found at the western-most extent of these rocks and have a distinctively different phase assemblage from other NMM jadeitite, including Sr-rich zoisite, pumpellyite, grossular, and K-feldspar, as well as appearance (Table 1; Harlow et al., 2011). Mostly medium green jadeitite has been recovered from the eastern limit of occurrences, but this material is not distinctive in terms of phase assemblage compared to the bulk of jadeitite north of the MFS. An important mineralogical characteristic of NMM jadeitite is the lack of quartz, which both indicates silica activity (with implications noted above) but also permits jadeitite to form at $\mathrm{PT}$ conditions between the $\mathrm{Ab}=\mathrm{Jd}+\mathrm{Qz}$ and $\mathrm{Ab}+\mathrm{Ne}=\mathrm{Jd}$ or $\mathrm{Anl}=\mathrm{Jd}+\mathrm{H}_{2} \mathrm{O}$ reactions (i.e. at lower P: see Fig. 8 , Harlow et al., 2011). The jadeitite blocks show cataclastic to sheared textures in addition to the veins. Albitization around block margins and fractures post-dating Jdveining is common; complete replacement of jadeitite by albitite typically occurs toward the boundary of a block with serpentinite host, if contact relationships can be observed. Ultimately, there appear to be a replacement type and a primary type that may mimic the two types of jadeitite found world-wide, cited above. The primary-style albitite can contain cavities with wellformed, transparent, twinned albite crystals to $2 \mathrm{~cm}$ in maximum dimension. Omphacitites have a similar appearance to jadeitite but are darker green and commonly have finer grain size. There is 
an intimate association of jadeitite and albitite north of the MF, which is in part due to the alteration of jadeitite to albitite, but albitite also occurs as a distinct rock without apparent replacement texture (Harlow, 1994). Albite-phengite rocks and phengite rocks consist of white sugary albite and variably coarser (grains $\leq 1 \mathrm{~cm}$ ) tan phengitic muscovite with rare appearance of any foliation. These two mica-rich lithologies may be transitional from albitite, but relationships are not always clear.

\subsection{South of the MFS}

Jadeitite and omphacitite are generally found as boulders and cobbles in rivers and drainages (quebradas in Spanish) of the mountainous region. Albitite and phengite-albite rocks are essentially absent, although phengite-rich jadeitite is found. There are three distinct areas in the mountains of Jalapa and Zacapa departments with very small areal distributions, typically of one to several kilometers. They are near the towns of Carrizal Grande, La Ceiba, and La Ensenada (Fig. 1; also Figs. 1 and 3 in Harlow et al., 2011) and are all within 12 km of one another (a finer scale map appears as Fig. 3 in Harlow et al., 2011).

In the Carrizal Grande area, furthest west, the jadeitite occurs mostly as isolated blocks with ill-defined contacts to adjacent serpentinite or in the drainages of several quebradas. Upslope and up-stream limits appear to align with minor fault traces cutting subparallel to the overall serpentinite fault boundary. Jadeitite is generally massive and often contains conspicuous phengitic muscovite or lawsonite crystals, commonly with inclusions of jadeite. Color is light to medium to medium-dark green with occasional dark blue-green veins colored by blue omphacite (Harlow et al., 2004b). Coexisting lithologies include lawsonite eclogite, blueschist-altered eclogite, lawsonitite, glaucophane-omphacite rock, garnet-quartz-phengite schist, and graphite-bearing quartz-mica schist (Tsujimori et al., 2006a). Near La Ceiba the 
jadeitite is tightly confined to a 100 meter wide exposure in serpentinite (no contacts exposed) as blocks to a few meters in size. Smaller blocks litter a quebrada below this exposure. The jadeitite is generally medium to dark green, on occasion intensely green, and fine-grained to microcrystalline but highly fractured. In rare cases jadeitite blocks are encapsulated by a diopside-rich rock, probably a late-stage rind formation. Coexisting tectonic blocks in the area are omphacite-glaucophane blueschist and epidote-amphibolite. Jadeitite from both these localities can contain quartz coexisting with jadeite, with significances as explained for NMM jadeitite. Finally, near La Ensenada in a serpentinite slice further north, in and around an E-W trending quebrada are dismembered blocks ( $\leq 3 \mathrm{~m}$ across) of a whitish gray jadeitite with green, blue, orange (grossular), and mauve streaks and spots that is a fine-grained jadeite-pumpellyite rock (this material has been sold as jade lila or rainbow jade). It occurs interlayered with a pale brown chloritite, and the associated lithologies are lawsonite blueschist and a partially amphibolitized-chloritized serpentinite. A single other occurrence of this material is found $\sim 3$ $\mathrm{km}$ east and appears to be in the same fault slice of serpentinite.

\section{Analytical Techniques}

Identification of minerals in these rocks reported in Table 1 was accomplished by petrography of thin sections, $\mathrm{X}$-ray diffraction, microprobe, and energy dispersive semiquantitative analysis. Techniques are described in Harlow et al. (2011). Whole-rock analysis was performed on rock samples, cleaned of weathered exteriors, weighing more than $50 \mathrm{~g}$ at the Washington State University GeoAnalytical Laboratory by X-ray fluorescence for major and minor elements (rock powders) and by inductively-coupled mass spectrometry for trace elements (dissolved powders); details of the laboratory's procedures can be found at the URL: http://soe.wsu.edu/facilities/geolab. Certain samples (marked by the symbol ${ }^{\circledR}$ after the sample 
number) were reanalyzed from the same powder and are included as evidence of reproducibility of analysis (different samples were chosen by WSU for XRF and ICPMS for these tests of reproducibility). Other samples, such as MVE07B-5-1 and MVE07B-5-3 were sampled twice and show the homogeneity of the rocks (or lack thereof) even though the rocks appeared sufficiently homogeneous for the sample sizes. These samples are designated by the letter $\mathrm{R}$ after the sample number. Both sets of analyses are presented in Table 1 and in the figures.

The above two listed samples do show differences in the REE, Th, U, Zr, and Hf, but not in other elements (see trace element section on albitites, below) suggesting a distinct nugget effect, as might be due to more zircon or monazite in one aliquot than another. This characteristic is undoubtedly expected more in these vein rocks than in extensive igneous bodies and is one of the reasons for the large number of samples processed in this study. Consequently, it is either in the uniformities of trace-element concentrations within a group of rock analyses or the recognizable effect of a trace-element rich phase on the whole-rock composition that permit making generalizations from these compositional data.

\section{Results}

We have sorted the samples and the results into groups by rock type (e.g., jadeitite, omphacitite, albitite) and by regions for both the NMM and the SMM. This was done to be able to look for differences based on mineralogy of the main rock types and the spatial distribution. In the NMM, with a length of over $230 \mathrm{~km}$ of serpentinite bearing jadeitite, groupings from west to east are W. Jadeitites (three western most jadeitite areas—-black symbols in Figure 1, near Saltán), Manzanal (grouping with brown symbols in Figure 1), Sierra de Las Minas (blue symbols), La Palmilla (a major source, green symbols), Panaluya (red symbols), and E. Jadeitites (orange symbols near Rosario in Figure 1). In the SMM there are the three distinct sources of 
Carrizal Grande area (purple symbols in Fig. 1), La Ceiba (dark red symbols in Fig. 1) and La Ensenada (dark green symbols in Fig. 1). Another group of jadeitite was collected as cobbles from the Rio El Tambor (pink symbols near El Tambor in Fig. 1) and was added both for gaining more data and to see whether there was preferred sampling by the river. Differentiating between NMM and SMM is important because the two mélanges are distinctly different in age, PT histories and origin; these differences show up in the differences of the rocks as well, even if formed by comparable processes.

\subsection{Jadeitites}

Major Elements - Dominance of jadeite in these rocks is obvious in the greater abundance of major oxides $\mathrm{SiO}_{2}\left(56.65-61.75\right.$ wt.\%), $\mathrm{Al}_{2} \mathrm{O}_{3}\left(21.43-24.97\right.$ wt.\%), and $\mathrm{Na}_{2} \mathrm{O}$ (9.88 - 14.42 wt.\%), relatively low abundance of $\mathrm{TiO}_{2}, \mathrm{MnO}, \mathrm{K}_{2} \mathrm{O}$, and $\mathrm{P}_{2} \mathrm{O}_{5}$ and low but variable $\mathrm{CaO}\left(0.22\right.$ - 3.18 wt.\%) $\mathrm{MgO}\left(0.05-2.48\right.$ wt.\%) and $\mathrm{FeO}^{*}(0.05-1.82$ wt.\%; $\mathrm{FeO} *$ is total iron oxides expressed as $\mathrm{FeO}$ ) because of solid solution with quadrilateral pyroxene and aegirine. $\mathrm{K}_{2} \mathrm{O}$ content $(0.01-1.85 \mathrm{wt} . \%)$ is largely an indicator of $\mathrm{K}$-bearing mica (phengite or, less importantly phlogopite/biotite) but in a couple of cases K-rich feldspar, which is generally less abundant in the NMM jadeitites and more in SMM ones from Carrizal Grande. Ca, Mg and Fe are generally correlated and reflect the solid solution toward omphacite (and aegirine) in the jadeite or actual omphacite as a phase, coexisting or as an overgrowth on jadeite (see Harlow et al., 2011). Again, these $\mathrm{Di}+\mathrm{Hd}+\mathrm{Ae}$ components are generally lower in true jadeitites from the NMM than the SMM. $\mathrm{TiO}_{2}$ content generally reflects the presence of titanite which is less abundant in NMM jadeitites. Seven major elements are plotted in Figure 2 for all analyses. This figure shows that none of the rocks are simple mixing of the reservoirs of subducted materials. 
Jadeitites from the NMM show evidence of varying albitization or retrogression (formation of analcime or albite plus nepheline at the expense of jadeite), which shows up in the major elemental analyses in two ways: Increase in $\mathrm{SiO}_{2}$ (and reduction of $\mathrm{Al}_{2} \mathrm{O}_{3}$ and $\mathrm{Na}_{2} \mathrm{O}$ ) from increase in albite during albitization and higher value of loss on ignition (LOI) from the reaction $\mathrm{Jd}+\mathrm{H}_{2} \mathrm{O} \rightarrow$ Anl. Examples of such jadeitite samples include MVE07B-3-3 and MVE07B-6-1, which exhibit albitization, and MVE06-12-1, which contains abundant analcime as well as minor but noticeable zoisite and taramite. The inversion $\mathrm{Jd} \rightarrow \mathrm{Ne}+\mathrm{Ab}$ in MVE07-10, which is mostly in the form of an Ab-Ne symplectite (but kept in the mix of samples for comparison), yields a composition that is nearly identical to a jadeitite in terms of major element composition. Among these, no major differences in major element compositions are manifest based on the broad geographical distributions shown in Tables 1 and 2. However, a set within the group of La Palmilla samples in which only paragonite (and preiswerkite) is present is distinctive for lower $\mathrm{K}_{2} \mathrm{O}$.

Jadeitites from the SMM are mainly differentiated from each other by mineralogy more than major element composition (see above and Harlow et al., 2011), which shows up most clearly in compositions as $\mathrm{K}_{2} \mathrm{O}$ content from phengite in many samples of jadeitite from the Carrizal Grande area and $\mathrm{TiO}_{2}$ content from titanite and rutile.

Trace and Rare Earth Elements - Concentrations and variations in trace elements also correlate with mineralogy of jadeitite and present patterns suggesting variations depending on geographic source in the NMM. Figure 3 presents REE data for jadeitite normalized to primitive upper mantle (PUM) composition (McDonough and Sun, 1995) and compared to relevant compositions from reservoirs of oceanic rocks including normal mid-ocean ridge basalt and ocean island basalt (N-MORB and OIB: Sun and McDonough, 1989) and global subducting 
sediment (GLOSS: Plank and Langmuir, 1998). More complete trace element plots as spidergrams for jadeitite are presented in Figure 4. Because the studied rocks are not igneous products but fluid crystallization or metasomatic products, the spidergrams are organized by increasing bond-strength (ionic radius for 6-fold coordination divided by nominal charge; radii from Shannon, 1976) rather than "compatibility." Nickel and chromium were included, in particular, to assess input from hydrated peridotite of the serpentinized ultramafic host. Data in Figure 4 are normalized to N-MORB (Sun and McDonough, 1989; Ni, Cr and Sc are estimated from Klein, 2003)

First, it must be pointed out that at low concentrations, near or below the detection limit, such as for MVJ84-3-2 from Manzanal, the REE patterns (Fig. 3) are not well constrained. However, we have chosen to plot analyses below the detection limit at the detection limit, rather than to plot nothing in order to show their depleted character. Most jadeitites from the NMM show a modestly depleted REE pattern compared to PUM, with a slight concave-upwards shaped pattern but variable to nonexistent Eu anomaly. There are a few jadeitites from the NMM, particularly from the W. Jadeitites and a few from Sierra de Las Minas with REE approaching or exceeding N-MORB, with convex "curvature" and more pronounced Eu anomalies. Manzanal jadeitites are the most depleted and generally below our detection limits. There is some consistency in the patterns of the different selected geographic areas, such as lower for Manzanal, La Palmilla, and Eastern from the NMM and higher for Western and Panaluya jadeitites. Most of the patterns from the SMM jadeitites show light REE enrichment and flat to concave patterns from the middle to heavy REE. Eu shows a slight negative to no anomaly except in the jadeitites from La Ensenada, which show a distinct positive Eu anomaly and are generally more depleted. 
The N-MORB-normalized minor and trace element patterns in Figure 4 are conspicuous for a number of characteristics. All patterns show strong $\mathrm{Cs}$ and $\mathrm{Ba}$ enrichment relative to $\mathrm{K}$ and $\mathrm{Rb}$, and the enrichment of $\mathrm{Cs}$ and $\mathrm{Ba}$ compared to N-MORB can range from greater than 1000 to none, at all: $\sim 1$. Th and $\mathrm{U}$ are enriched compared to the REE and $\mathrm{Sc}$ (as well as $\mathrm{Cr}$ ), as are $\mathrm{Zr}$ and Hf. Among most NMM jadeitites, Th/U generally ranges from 0.1 to 2 with a few high values to 8.8 and 12, whereas among SMM samples, the values are generally higher and more variable, from 0.4 to 8.6 , without the outliers (average Th/U for values of 2 to 4 for most oceanic igneous rocks, $\mathrm{CI}$ and even sediments). Likewise, $\mathrm{Hf}$ is usually somewhat more enhanced than $\mathrm{Zr}$ among NMM jadeitite (average $\mathrm{Zr} / \mathrm{Hf}=24$ versus 36 for $\mathrm{N}-\mathrm{MORB}$ or 32-36 for CI chondrite) but the two elements are equally enriched in SMM jadeitite (average $=36$ ). The elements that generally show relative depletion are $\mathrm{K}, \mathrm{Ni}, \mathrm{Sc}, \mathrm{Cr}$, and $\mathrm{Ti}$

\subsection{Omphacitites and Jadeite-omphacitites}

Major Elements - The dominance of omphacite in these rocks is reflected in the abundance of major oxides $\mathrm{SiO}_{2}\left(54.53-63.72\right.$ wt.\%), $\mathrm{Al}_{2} \mathrm{O}_{3}\left(8.65-17.75\right.$ wt.\%), $\mathrm{Na}_{2} \mathrm{O}(5.56-$ 10.43 wt.\%), $\mathrm{CaO}(6.22-12.44$ wt. \%), $\mathrm{MgO}(2.33-9.77$ wt.\%), $\mathrm{FeO} *(0.28-8.45$ wt. $\%)$ and a relatively low abundance of $\mathrm{TiO}_{2}(<1 \mathrm{wt} . \%), \mathrm{MnO}, \mathrm{K}_{2} \mathrm{O}$, and $\mathrm{P}_{2} \mathrm{O}_{5}$ (Appendix A). This group manifests a greater compositional variation than the jadeitites as a group, because they show a greater range of Jd-Omp in the bulk compositions. The single lawsonite omphacitite sample (MVE02-15-5) has lower $\mathrm{SiO}_{2}$ and higher $\mathrm{Al}_{2} \mathrm{O}_{3}$ and $\mathrm{CaO}$, in particular, than the other types. $\mathrm{K}_{2} \mathrm{O}$ content is low $(0.00-0.65$ wt. $\%)$ in all samples but two: MVE03-77-7 (3.04 wt.\%) and MVE02-15-5 (1.16 wt.\%), the lawsonite omphacitite. Thus, these two are the only such rocks with appreciable phengite and K-feldspar, respectively, and are from the SMM, like the more Krich jadeitites. Otherwise, there is no particular distinction in major element chemistry between 
NMM and SMM omphacitites. However, as omphacitites are less abundant than jadeitites, and thus fewer were collected from all of the source areas, the number of samples analyzed and their geographic distribution are considerably reduced.

Trace and Rare Earth Elements - Normalized concentrations of trace elements are plotted in Figures 5 and 6 for REE and spidergrams, respectively, in the same manner as for jadeitites. There is a REE trend among the samples for two different limiting profiles: One is light-REE enriched, sloping down to Eu and then a relatively flat to having slightly lower values toward Lu. The other is slightly light-REE depleted sloping upward to Eu and then relatively flat to $\mathrm{Lu}$. These differences may be source specific but appear to be repeated geographically, within both the NMM and the SMM. The most obvious difference in REE between omphacitites and jadeitites is the generally greater abundance in omphacitites, by almost an order of magnitude. This is probably controlled in part by pyroxene crystal chemistry, in that low-Ca jadeite does not provide the appropriate atomic siting for REE as does omphacite.

The spidergrams of minor and trace elements (Fig. 6) share some features observed in the comparable jadeitite patterns. They all are relatively enriched in $\mathrm{Cs}, \mathrm{Ba}$, Th, and $\mathrm{U}$, although not always to the same extent. The differences described for the REE plots extend to the spidergrams; specifically most omphacitites with relatively flat REE or LREE depleted patterns (e.g., JJE01-7-7, MVE04-25-6, MVE02-14-5) tend to be relatively enriched in Ni and $\mathrm{Cr}$ and depleted in $\mathrm{Zr}, \mathrm{Hf}, \mathrm{Ti}, \mathrm{Nb}$ and $\mathrm{Ta}$. These suggest differences in the source of solute for these fluid crystallization products that will be discussed below.

\subsection{Albitites}

Albitites are differentiated from albite-jadeitites by the lack of observed jadeite in thin section, rather than by whole rock compositions, which overlap for the major elements. One 
sample, MVE07B-17-2 has been grouped with the albitites because it fits better in this group mineralogically than in the albite-mica rocks or albite jadeitites, based on albite abundance and lack of jadeite in the sample. There is also the question of identification of albitite versus metatrondhjemite, which may be among the samples and will be discussed later.

Major Elements - Albitite compositions strongly resemble that of albite, diluted mostly by minor K-rich mica, tremolitic amphibole, omphacite/diopside, and/or quartz: $\mathrm{SiO}_{2}=64.8-$ 73.9 wt. $\%$ (68.7 for pure $\mathrm{Ab}$ ), $\mathrm{Al}_{2} \mathrm{O}_{3}=15.7-20.5$ (19.4) wt.\%, $\mathrm{Na}_{2} \mathrm{O}=7.0-11.74$ (11.8) wt.\% (except 3.6 in MVE07B-17-2), with $\mathrm{CaO}<2.4$ wt.\%, $\mathrm{K}_{2} \mathrm{O}<2.4$ wt.\%, $\mathrm{MgO}<1.3$ wt.\%, $\mathrm{FeO} *<$ 0.44 wt. $\%$, and $\mathrm{TiO}_{2}<0.14$ wt.\% in all samples but one for each oxide. All but one sample is sourced from the NMM, which has been pointed out as a fundamental difference between the mélange blocks from the two mélanges (Harlow et al., 2011). Harlow (1994) suggested a differentiation between albitites that are altered/metasomatized jadeitite versus those that are similar to albite-mica rocks (those bearing phengite like the mica-rich rocks) and are probably fluid crystallization products (a R-type and P-type for albitites). Although potassium content might be considered a good discriminant, it does not serve to discriminate between these two types of albitite. Upon comparing Tables 1 and 2 for example, MVE06-4-3 and MVE07B-5-3 which contain phengite are not as K-rich as MVE06-4-4 or MVR07-26F, which contain talc + Kfeldspar + celsian + hyalophane or biotite respectively.

Trace and Rare Earth Elements - Most of the REE patterns for albitites from the NMM presented in Figure 7 are generally flat with variable positive Eu anomalies and are depleted to $0.01-0.2$ of PUM values. The exceptions are three samples among the Western NMM group and MVJ90-4-2, a quartz-bearing possible meta-trondhjemite, from the Manzanal area. The sole 
sample from the SMM, MVE04-21-2 (La Ensenada), with jadeite, grossular, and quartz in addition to albite, has a pattern more similar to SMM jadeitites (Fig. 3).

The spidergrams of trace elements in albitites are presented in Figure 8. Again, among the NMM samples there are generally relative enrichments in $\mathrm{Ba}, \mathrm{Th}, \mathrm{U}, \mathrm{Zr}$, and $\mathrm{Hf}$ compared to depletions in $\mathrm{Ni}$, the REE, Sc, $\mathrm{Cr}$, and $\mathrm{Ti}$. $\mathrm{Cs}$ and $\mathrm{Rb}$ are more variable in degrees of enrichment, with $\mathrm{K}$ being depleted relative to other LILEs but not to N-MORB, except in Western samples which can contain phases like K-feldspar and hyalophane. Also, whereas Ta is less depleted than $\mathrm{Nb}$ in jadeitites, there is no general relationship among the albitites. Finally, two samples were sampled twice among the La Palmilla albitites - MVE07B-5-1 and MVE07B-5-3, and there are clear differences in the trace elements (particularly the REE, Th and $\mathrm{U}$ ) between each pair, which suggests a nugget effect from minerals like allanite, monazite or zircon that were not even recognized. Given the sample size of $\sim 50 \mathrm{~g}$, these carriers must be scattered inhomogeneously in albitites. The single SMM sample, which shows a jadeitite-like and undepleted REE pattern, is otherwise similar to some of the other albitites from the NMM.

\subsection{Mica-albite and Mica Rocks}

These samples have been found only in the NMM and were not broadly sampled for this study, constituting only seven samples.

Major Elements - These rocks are characterized by their relatively high $\mathrm{K}_{2} \mathrm{O}$ content (5.3 - 9.7 wt.\%), $\mathrm{Al}_{2} \mathrm{O}_{3}\left(25.5-29.6\right.$ wt.\%), and LOI (2.7 - 4.6 wt.\%) but somewhat low $\mathrm{SiO}_{2}(47.3-$ $56.2 \mathrm{wt} . \%$ ) compared to other rock types in this study. The signature of phengitic muscovite is the moderate $\mathrm{MgO}\left(1.6-4.8\right.$ wt.\%) and somewhat lesser $\mathrm{FeO}^{*}(0.8-1.6$ wt.\%) without $\mathrm{CaO}$ $(0.0-0.5$ wt. $\%)$ content from calcium-bearing pyroxene or amphibole component. The variable albite content shows up in $\mathrm{Na}_{2} \mathrm{O}(0.46-5.43$ wt. $\%)$. 
Trace and Rare Earth Elements - Trace elements for these rocks are grouped together in plots of REE and a spidergram in Figure 9. The REE plots of mica rocks all have concave shape, LREE somewhat higher than HREE, and a conspicuous positive Eu anomaly. In contrast, the mica-albite rock REE are flatter, still, with higher LREE, and the positive Eu anomaly is smaller to slight. Both suites show about an order of magnitude variation in abundances, generally with mica rocks values lower, generally below PUM and mica-albite rocks somewhat higher to above PUM.

As should be expected, the spidergrams are conspicuously enriched in LILE, particularly in $\mathrm{Ba}$, and share the relative enrichment in $\mathrm{Th}, \mathrm{U}, \mathrm{Zr}$, and $\mathrm{Hf}$ and depletion in $\mathrm{Ni}, \mathrm{Sc}, \mathrm{Cr}$ and $\mathrm{Ti}$ with jadeitites, but they have less $\mathrm{Pb}$ and $\mathrm{Sr}$ than jadeitites. The high LILE and low $\mathrm{Sr}$ are consistent with abundant phengite and albite, although the scatter in REE might be expected to be smaller if only dependent upon these two main constituents. There do not appear to be any noteworthy differences based on the geographic distribution, however there are probably not enough samples to derive such distinctions at this stage.

\section{Discussion}

As this is the first attempt to present a large suite of whole rock analyses of jadeitites and rocks interpreted as of similar origin, there are a variety of opportunities and challenges to their evaluation and interpretation. A first order assessment has to do with the carriers of the traceelement signal. The first question concerns rocks that are dominated by a single mineral, such as jadeite in jadeitite; which mineral in these rocks carries the signature element or elements. So, how much is due to jadeite (and its diopside content) versus some critical carrier like zircon for $\mathrm{Zr}$ and Hf, allanite for HREE or phengite, cymrite and celsian for Ba? How do Guatemala jadeitites compare with the limited comparable data for those from elsewhere, such as Myanmar, 
Japan or the Cyclades? How do the trace elements compare with those from the rocks and sediments entering a subduction zone, as was done by Simons et al. (2010) in trying to understand the Li signature of some GSZ jadeitites? This comparison of constituents within a subduction channel relates to the two competing hypotheses for the origin of jadeitites (here specifically for the Guatemalan samples): fluid precipitates representing complete (or nearly so) fluid-mediated transport of solutes into lithic crystallizations (P-type) or metasomatic modifications of a preexisting rock (R-type), as discussed in the introduction. Then we examine the other rocks - omphacitites, albitites, and mica-rocks. Albitites pose a particularly interesting case because there are many other geologic contexts where they form, plus they show certain similarities to trondhjemites (plagiogranites in some ophiolitic contexts) and tonalites.

First, the extant literature on whole rock compositions for these rocks must be addressed in order to make comparisons.

\subsection{Jadeitites}

In order to evaluate the degree to which some of the trace elements in the jadeitite whole rock data reflect jadeite as the primary constituent, an examination of jadeite trace element compositions is needed. Whereas there are now numerous major element compositions by microprobe, the trace element analyses are limited. Sorensen et al. (2006) used SIMS to examine jadeite in jadeitite from several localities including Guatemala, using CL color zoning as a guide. Morishita et al. (2007) measured trace elements by LA-ICPMS in jadeite and omphacite from jadeitite of the Itoigawa-Ohmi district, Japan. Simons et al. (2010), in an examination of whole rock compositions and the first data on $\mathrm{Li}$ content and $\delta^{7} \mathrm{Li}$, reported on some whole rock jadeitite compositions and some mineral separates; however, as these do not really include

mineral analyses, no separates data are compared here. Finally, Harlow and Shi (2010) reported 
on trace element compositions of lavender-colored jadeite from Myanmar, Japan, and Guatemala using LA-ICPMS, although portions of their data are reported for the first time here. Results for jadeite and omphacite are summarized in Figure 10, normalized to N-MORB so as to be comparable to the whole-rock analyses in Figure 4. Lithium and $\mathrm{Ca}$ have been included in Figure 10, in part because these are available and, in particular, for Ca because it is the cation for which REE substitutions are expected to occur in clinopyroxene and, thus, may influence REE uptake. Many analyses are reported either with a value of zero or "below detection limit", so that detection limits are plotted for all analyzed elements, where available, as a maximum estimate for those cases.

Jadeite: First, in looking at the available data, two deviations are noteworthy. The Sc values from Sorensen et al. (2006) are always higher than in other analyses and inconsistent with the REE trends and there is a depletion of Y only in the jadeite data of Morishita et al. (2007).

In comparing Guatemala whole-rock data, reported above, and jadeite data from Guatemalan jadeitites, only one sample is in both sets: MVE04-44-1. Ba, Pb, and Sr (the only large ions reported in both data sets) are depleted in jadeite compared to the whole rock, by about an order of magnitude. This is consistent both with the crystal chemistry of jadeite and with the fact that other phases, such as phengite, K-feldspar, and banalsite, host the large ions in jadeitite. For other elements conspicuous in the whole rock data and reported from both sets of data, U and $\mathrm{Zr}$ are roughly two orders of magnitude higher in the whole rock than in jadeite. REE show higher concentrations in the more calcic jadeite (MVE04-44-1 R: Jd85) than in near end-member jadeite (MVE04-44-1 C: Jd98) by at least an order of magnitude, but their concentrations are below the whole rock values and with a flatter, slightly concave, pattern. 
There appears to be more scatter among the Guatemala jadeite data than in those from the other sources. It is not clear whether this is just an issue of the number of samples from each source and not having as comparable suite of elements among the analyses, such as complete REE data, or greater real variation among the measured Guatemala jadeite samples. The LILE, particularly Ba, are generally low in jadeite, as should be expected. Some higher Ba values may reflect hitting micro- or nano-inclusions of barite or other Ba-rich mineral that have been reported in such samples by Harlow et al. (2012). Some of the $\mathrm{Zr}$ and Hf concentrations in the Myanmar and Itoigawa jadeite data show a relative increase compared to the adjacent elements, as in many of the Guatemalan whole rocks; however, this is not evident among the rest of the jadeite data. REE concentrations appear to be variable (as in the Guatemala whole rocks) with a suggestion of concentrations correlated with Ca content, but there is a largely consistent pattern with a relatively flat shape to slightly more depleted relative to N-MORB with increasing atomic number (decreasing ionic radius).

The jadeite data reported here (Fig. 10) represent only P-type, as interpreted by the various authors. Jadeite and omphacite in jadeitite from the Itoigawa-Omi district, Japan (Morishita et al., 2007) display elevated Li, generally comparable LILE, LREE > HREE and positive anomalies of high field-strength elements (HFSE) relative to N-MORB or primitive mantle. These authors attributed this signature to slab-derived fluids relatively rich in LILE and HFSE from interaction with subducted crust and serpentinized peridotites. In their data, only Li, $\mathrm{Ni}, \mathrm{Zr}$, Hf, and $\mathrm{Nb}$, among elements measured in jadeite exceed N-MORB concentrations (Ni may reflect a detection problem). $\mathrm{Sr}$ and $\mathrm{Cr}$ are higher (but $\mathrm{Nb}$ is lower) in omphacite. This difference may demonstrate the importance of crystal chemistry, when considering how trace elements are accommodated by the crystal structures (e.g., Sr into Ca-rich omphacite, Li into Na- 
rich jadeite and omphacite). Alternatively, it may reflect different stages of precipitation, as omphacite is usually late in jadeitites, perhaps due to release of $\mathrm{Ca}$ from ultramafic rocks into the fluid after extensive serpentinization of peridotite. Sorensen et al. (2006) were guided by CL images of zoning in jadeite grains in jadeitite from Burma, Guatemala, Japan, Kazakhstan, and California, for their SIMS analyses. They reported trends of increasing $\mathrm{Ca}, \mathrm{Mg}$, and $\mathrm{Cr}$ in traversing from early red and blue CL zones toward later green zones, typically with an increase in elements such as $\mathrm{Li}, \mathrm{Rb}, \mathrm{Sr}, \mathrm{Ti}, \mathrm{Hf}, \mathrm{Zr}$, and light rare-earth elements (LREE). They argued that this change indicated the role of the fluid in controlling these changes; for example, increased Li is not correlated with Na content and thus Na site occupancy. Comparing the trace element abundances in jadeite and omphacite shows the effect the clinopyroxene composition has on jadeitite bulk composition, but clearly certain trace elements are also hosted in minor and accessory minerals, which greatly affect the whole-rock budget of these elements. Ca content in jadeite does appear to play a role in the REE content variation between different samples. Nonetheless, fluid chemistry or crystallization temperature may be more significant to these signatures, as suggested in the Sorensen et al. (2006) data. Thus, more and better trace-element measurements are probably required to isolate the effects of mineral chemistry, accessorymineral solubility and fluid chemistry.

Comparing various P-type jadeitites: A limited quantity of whole rock analyses is available to compare with those from Guatemalan samples. Starting with jadeitite interpreted as predominantly of P-type, the most comprehensive and consistent data are for samples from the Jade Mine Tract in Myanmar (Shi et al., 2008). These samples show an enrichment of Ba but not $\mathrm{Sr}$, but also high $\mathrm{Pb}$, variable $\mathrm{U}$ ( 0.01 to $0.3 \mu \mathrm{g} / \mathrm{g}$ ) and variable $\mathrm{Th} / \mathrm{U}$ ( 0.5 to 1.5 ; moderate $\mathrm{Zr}$ (19 to $45 \mu \mathrm{g} / \mathrm{g}$ ) with $\mathrm{Zr} / \mathrm{Hf}$ (23 to 36 ) low $\mathrm{Rb}, \mathrm{K}$, and $\mathrm{Ti}$, and concave REE patterns, roughly two 
orders of magnitude below N-MORB, with a positive Eu anomaly, shown in Figure 11, analogous to Figure 4 for Guatemala jadeitites. Analyses for two samples from Yui et al. (2013) are somewhat different and different from one another, conspicuously higher in REE (one without the concave appearance), variable Th/U (0.66 and 22.7), much higher Zr (169-144) and $\mathrm{Hf}(\mathrm{Zr} / \mathrm{Hf}=33-44)$. Some of the differences compared to the Guatemalan jadeitite data can be explained by the different mineralogy and pyroxene composition. Myanmar jadeitites contain minor Ba- rich minerals and can contain sodic amphiboles like eckermannite and glaucophane but lack any mica (see Shi et al., 2012). This is consistent with low LILE. Myanmar jadeitites contain jadeite that is generally closer to end member composition and little-to-no omphacite. Thus, following the interpretation above, the REE contents are more similar to the NMM jadeitites that also contain less Ca-component pyroxene. Recent examination of zircon in Myanmar jadeitite has interpreted them as inherited from a protolith of Jurassic age rather than crystallized from a fluid (Yui et al., 2013), compared to a rim ages of zircon being $~ 15 \mathrm{Ma}$ younger to late Cretaceous. However, textural evidence in the rocks, including fluid inclusions, lack of pseudomorphism, and rhythmic zoning of jadeite argues that the bulk of the jadeitite is primary, thus dominantly P-type but masking or overwhelming a R-type precursor. This apparent paradox is probably not uncommon, that the metasomatic portion leaves only the most refractory minerals of the protolith, like zircon grains, while fluid crystallized jadeite is added without leaving recognizable pseudomorphic relics. Nonetheless in terms of $\mathrm{Zr}$ and $\mathrm{Hf}$ (or $\mathrm{Zr} / \mathrm{Hf}$ ), there is little difference between the two occurrences (except perhaps the two samples of Yui et al., 2013 with higher than average values); whole rock data do not appear able to distinguish this difference in zircon origin in the jadeitites, further complicating recognizing any traces of a R-type component, which may only be in the small quantity of zircon grains. 
Simons et al. (2010) presented data on a single sample from the SMM of Guatemala, which can be compared with the new data presented here. Sample MVE02-8-5 (Carrizal Grande) has been reanalyzed. Generally the data show similarities, but given the consistency in the new data, we prefer them to that from Simons et al. (2010).

Syros and Tinos jadeitites are categorized as a mixture of P-type and R-type, so interpreting the jadeitite compositions (Bröcker and Enders, 2001) is potentially problematic; nonetheless the plotted data (Figure 11) are quite consistent with $\mathrm{Ba}>\mathrm{K} \approx \mathrm{Sr}$, enriched $\mathrm{U}(\geq \mathrm{Th}$ ), $\mathrm{Zr}(>\mathrm{Hf}), \mathrm{Nb}, \mathrm{Ta}$, and flat, somewhat enriched REE patterns. Data from other P-type jadeitite sources (e.g., Itoigawa-Omi: Miyajima, 1999 and Sorkhan, Iran: Oberhänsli et al., 2007) are very incomplete and therefore not considered. In spite of the differences, among the P-type jadeitites there are similarities in enriched $\mathrm{Ba}( \pm \mathrm{Pb}$ or $\mathrm{Sr})$ among the LILE, $\mathrm{U}( \pm \mathrm{Th})$ compared to the REE, and perhaps $\mathrm{Zr}$ and $\mathrm{Hf}$ as well. Presumably these features represent some common combination of source of the solute, namely the subduction channel constituents, and relative solubility in some hydrous fluid transiting or escaping from it with an unknown but sufficient flux to crystallize considerable volumes of jadeitite.

Source of solutes for P-type jadeitites - Guatemala and elsewhere: The candidates for the source of solutes that precipitated jadeitites as well as other P-type rocks such as albitites and mica rocks are the subduction channel constituents: subducted altered oceanic crust (AOC), subducted sediment, and possibly some admixture with the subduction channel roof - the mantle wedge. Simons et al. (2010) examined these possibilities in their study of several Guatemala jadeitites and the constituents with a focus on Li content and isotopic signature. They reported that Li concentrations in jadeite $(\leq 90 \mu \mathrm{g} / \mathrm{g}$; somewhat less in jadeitite) were much greater than in N-MORB $(3-6 \mu \mathrm{g} / \mathrm{g}), \mathrm{IAB}(5-10 \mu \mathrm{g} / \mathrm{g})$ or AOC $(4-14 \mu \mathrm{g} / \mathrm{g})$ and generally isotopically heavier 
$\left(+2\right.$ to $+7.5 \%$ o $\left.\delta^{7} \mathrm{Li}\right)$ as compared to jadeitite and eclogite $\left(-5\right.$ to $\left.+5 \% 0 \delta^{7} \mathrm{Li}\right)$. These signatures are difficult to reconcile with a dehydration process by Rayleigh fractionation. On the other hand, sediments have both a greater $\mathrm{Li}$ concentration and lower $\delta^{7} \mathrm{Li}$ compared to AOC. Global Subducted Sediment (GLOSS; Plank and Langmuir, 1998) or its Li-evaluated counterpart Global Li Mass-weighted Sediment (GLiMM: $43 \mu \mathrm{g} / \mathrm{g} \mathrm{Li}, \delta^{7} \mathrm{Li}=3.01 \%$; Chan et al., 2006) and particularly sediments with a continental source affinity, such as the Lesser Antilles $(69.6 \mu \mathrm{g} / \mathrm{g}$ Li) were selected for modeling a dehydration path to yield a fluid from which jadeitite could be crystallized (Simons et al., 2010). Moreover, sediments are a potential source of elevated LILE and $\mathrm{Th}, \mathrm{U}, \mathrm{Zr}, \mathrm{Hf}, \mathrm{Nb}$ and $\mathrm{Ta}$, as can be seen in the whole-rock composition plots in Figures 4 and 11, to which GLOSS and Antillean Terrigenous sediment values have been added. $\mathrm{Li}$ is not included in these plots because there is only data on Li from Myanmar jadeitites (26 to $35 \mu \mathrm{g} / \mathrm{g}$ range for 6 samples, one at 5.8). However, Li is relatively high in jadeite in many, but not all, jadeitites (Fig. 11).

In the spider plots in Figures 4 and 11, differentiated igneous rocks and clay-rich sediments, as potential geochemical sources, generally show strong enrichments in LILE. Jadeitites follow a similar pattern but are generally less enriched in these elements, particularly if they do not contain phengite or a K-spar like phase, such as hyalophane, to host the large ions. Barium is interpreted as a reliable indicator of sediment, being greatly enriched in both pelagic and terrigenous clastic sediments (as shown in GLOSS data). However, it is not necessarily correlated with potassium because it resides in hosts such as barite, carbonate adsorption and in $\mathrm{Mn} / \mathrm{Fe}$ (e.g., Plank and Langmuir, 1998), a feature seen in the data. It is conspicuously high in most Guatemala, Myanmar, and Nishisonogi jadeitites (typically $50->250 \mu \mathrm{g} / \mathrm{g}$ ) and less so in Cyclades jadeitites $(20-77 \mu \mathrm{g} / \mathrm{g}$ ), but low abundances (as low as the N-MORB value of $\sim 6$ 
$\mu \mathrm{g} / \mathrm{g}$ ) have not been reported from any locality. Sr is modestly high in Itoigawa jadeitites (averaging $500-950 \mu \mathrm{g} / \mathrm{g}$ ) and moderately low in Guatemala, Cyclades, Myanmar, and Sorkhan jadeitites (typically $<50 \mu \mathrm{g} / \mathrm{g}$ ), whereas $\mathrm{Pb}$, in comparison to $\mathrm{N}-\mathrm{MORB}$, can be transitional between $\mathrm{Sr}$ and $\mathrm{Ba}$ (Guatemala, most Myanmar samples) or higher (Tone, Nishisonogi, two Myanmar samples: $\geq 8 \mu \mathrm{g} / \mathrm{g}$ ) in enrichment.

Nickel and Cr have been added to the plots as monitors of feedback from the ultramafic rock, which is typically the vein host. The evidence suggests fluid is absorbed during serpentinization, but release of $\mathrm{Ni}$ and $\mathrm{Cr}$ into a fluid exiting the ultramafic and contributing to jadeitite growth is not likely to occur until completion of serpentinization reactions or, alternatively, by mechanical mixing of the two lithological units. The values of $\mathrm{Ni}$ and $\mathrm{Cr}$ reported are very low, suggesting little geochemical contribution from ultramafic rocks during jadeitite crystallization. Moreover, the typical evidence of this is in the most valued emeraldgreen samples, for which $\mathrm{Cr}$ is chromophore; these are rare in general and within the samples studied.

Thorium, $\mathrm{U}, \mathrm{Zr}$, and $\mathrm{Hf}$ are high field strength elements that are generally considered less mobile in hydrous fluids. Jadeitites clearly show sympathetic variation within the element pairs (Th and $\mathrm{U} ; \mathrm{Zr}$ and $\mathrm{Hf}$ ) and varied concentrations, but following the pattern of sediment and evolved igneous rocks. These four elements are generally higher in the jadeitites from Cyclades and the SMM and lower in those from Myanmar and the NMM. The highest field strength pair is $\mathrm{Nb}$ and $\mathrm{Ta}$, which are less well constrained by multiple measurements but follow the trends of the previous four elements where measured, similar to sediment and ocean island basalt.

In conclusion, the enrichments in the LILE, $\mathrm{Ba}, \mathrm{Pb}$, and perhaps $\mathrm{Sr}$, as well as in $\mathrm{Li}$, are consistent with crystallization from fluids derived from a sediment-rich source and probably 
controlled in the jadeitite by compatibility in jadeite (for $\mathrm{Li}$ ) and in minor phases such as the Baor Sr-silicates, epidote-group minerals or mica (for the LILE). Potassium is usually depleted, particularly in comparison to $\mathrm{Ba}$, and even more so in samples without phengite (i.e., saturation of a K-rich phase). REE follow a flat to a sloping trend with LREE decreasing to the MREE and flat to the HREE, mimicking to some extent the pattern for GLOSS. The levels of REE in the majority of jadeitites are below N-MORB or GLOSS by one to two orders of magnitude, and the degree of depletion is typically inversely correlated with the Ca content of the average pyroxene. Enrichments in less "fluid-mobile" elements such as Th, U, Zr, Hf, Nb, and Ta appear to correspond to an enriched source, such as sediment. Transport and precipitation relates to solubilities at $\mathrm{HP} / \mathrm{L} T$ conditions and to fluid flux, as addressed below. This is not to suggest that the main bolus of solutes- $\mathrm{Na}, \mathrm{Al}$, and $\mathrm{Si}-$ does not come from altered oceanic crust, as Simons et al. (2010) have suggested. Dehydration of the subducted slab must be involved in producing the hydrous fluid, which is the major transport agent involved in the jadeitite formation process.

\section{A Signature for R-type jadeitites - Western Alps, Syros-Tinos, and Nishisonogi belt:}

None of the Guatemalan jadeitites have been interpreted as metasomatic replacements (R-type), but the data from jadeitites interpreted as R-type may provide only a fuzzy fingerprint. Jadeitite from Vallone Bulè, western Italian Alps (Compagnoni et al., 2012) has been interpreted as the desilicified cortex of a quartz jadeitite block in a basal serpentinite unit of the Monviso massif. This block was interpreted as a metaplagiogranite, originally formed in a near-ridge environment. The whole-rock data, replotted in Figure 11, for the jadeitite, quartz-jadeite and plagiogranite show a remarkable similarity with a somewhat enriched, relatively flat REE pattern; additionally, all of the related rocks show negative Eu anomalies, which is distinctive compared with most P-type jadeitites. Also in Figure 11 are the whole-rock data from Syros- 
Tinos jadeitite (Bröcker and Enders, 2001) and limited data from Nishisonogi jadeitite (Shigeno et al., 2012a). Yui et al. (2012) suggested that plagiogranite was a possible protolith for jadeitite (including that for the zircon in Myanmar jadeitite) so data from suprasubduction zone trondhjemite-tonalite-diorite of Shervais (2008) and a plagiogranite from the Lesser Antilles (Neill et al., 2010) are included. These rocks again show similarities to the jadeitites in their somewhat enriched and relatively flat REE patterns, in this case with only a hint of negative Eu anomaly. This feature may be the general signature for a trondhjemitic protolith. The Nishisonogi data are more similar to GLOSS, which may suggest a sedimentary protolith, rather than being a signature of an acidic igneous rock (i.e., a trondhjemite-tonalite-diorite or TTD, which is a potassium depleted version of the Tonalite-Trondhjemite-Granodiorite suite; e.g., Shervais, 2008) as suggested by the authors (Shigeno et al., 2012a). Thus, the interpreted kind of protolith and its trace-element signature, particularly REE, may be the best indicator for R-type jadeitite. If this interpretation is applied to the data from Guatemalan jadeitites, it would most likely point to the exceptional NMM jadeitite MVE07B19-1 or perhaps some jadeitite from the SMM. However, the strong Ba enrichment denotes fertilization from the fluid enriched with a sediment signature.

An alternate type of igneous protolith for R-type jadeitite is the slab-derived melt (partial melts from amphibole metabasite), as described by García-Casco and co-workers (e.g., BlancoQuintero et al., 2011; Lázaro et al., 2011; and Lázaro and García-Casco 2008) from the Sierra del Convento mélange in eastern Cuba. These have been argued as the protolith for jadeitite from the Sierra del Convento, however, these whole-rock jadeitite analyses have yet to be published. The features of the trace-elements, plotted in Figure 8 for albitites (rather than Fig. 11), have generally variable and more depleted REE patterns with more depleted HREE than the TTDs and 
plagiogranite, with uniformly lower reported $\mathrm{Th} / \mathrm{U}(0.88-1.96)$, generally high to remarkably high Zr/Hf (48 - 776), but highly variable LILE due to fertilization by hydrous fluid alteration. These features do not appear to have recognizable influences in any of the jadeitites plotted in Figure 11.

\subsection{Omphacite and omphacitites}

Data are more limited for both omphacite and omphacitite compositions, as presented in Figure 12, and there are no samples for which both mineral and whole-rock data are available. The mineral data from Itoigawa-Ohmi show the relatively low LILE content inherent in omphacite compared to all omphacitites from Syros-Tinos and a few from Guatemala which contain a K-rich phase such as phengite or K-feldspar (NMM: 01GSn1-4, MVE07B-3-1; SMM: MVE03-77-7, MVE02-15-5; see Table $1 \& 2$, Figure 6). It is not clear whether the somewhat depleted REE in omphacite compared to that in most omphacitites reflects only the presence of REE-rich phases such as allanite, monazite and titanite in the omphacitites from Syros-Tinos and Nishisonogi as well as many from Guatemala. However, the somewhat higher REE in omphacite compared to jadeite-omphacite and jadeite from Itoigawa-Ohmi supports the argument that omphacite is a more acceptable host for REE than jadeite, as argued earlier for Capoor and Ca-rich jadeitite from Guatemala.

The Nishisonogi omphacitites (Shigeno et al., 2012b) represent two different lithologic contexts. One is hosted in a metabasite: OM-Nishi (for Nishikashiyama), and the other in an albitite: OM-Mie. OM-Nishi has significantly more amphibole, epidote and titanite than OMMie, however, the REE are an order of magnitude more enriched in OM-Mie than in OM-Nishi, with the highest LREE $(\mathrm{La}=633$ times $\mathrm{CI})$ of any other rock sample considered here. Another element of interest in these rocks is $\mathrm{Pb}$, which is high ( 9 to $45 \mu \mathrm{g} / \mathrm{g}$ ), whereas $\mathrm{Ba}$ is 
conspicuously low. It is not clear how to compare these rocks with the Guatemala or other omphacitites given these differences and the lack of analyses for a range of elements.

A comparison of omphacitites with jadeitites from R-type jadeitite sources reveals a strong similarity in their REE patterns. Both jadeitite and omphacitite from Syros-Tinos share a relatively flat REE pattern and samples from the Nishisonogi area show similar sloped patterns, but are higher in LREE and lower in HREE. This may suggest either that the omphacitites are also of R-type, with the REE reflecting a possible restite signature or that, as would be the case with a P-type characteristic, the fluid precipitated this characteristic uniformly. Guatemala omphacitites are the only ones from a P-type source, but are represented by many more samples, and they show little uniformity among them or correlation with jadeitite REE patterns. However, there is an apparent division as in the case of the other omphacitites with either a relatively flat pattern or a relatively HREE depleted pattern. This may suggest the influence of a carrier for REE in a minor mineral, but we have not identified what mineral that may be.

Only the analyses of Syros-Tinos omphacitite include adequate measurements of the high-field strength elements to compare with Guatemala samples. The positive U-Th anomaly in these spider plots is shared by most samples in both sets of omphacitites. Some show an even greater enrichment in U compared to Th, whereas others have N-MORB-like Th/U ratio. Zr and Hf are somewhat enriched (>1 to 20 times N-MORB) in all but the jadeite-omphacitite samples. Those few omphacitites that do not show $\mathrm{Zr}$-Hf enrichment are restricted to Guatemala and typically demonstrate enriched $\mathrm{Cr}$ and $\mathrm{Ni}$. This could be a signature of a fluid that extracted ultramafic (like PUM or more depleted like harzburgite) components upon the final stages of serpentinization. 


\subsection{Albitites}

Harlow (1994) differentiated albitites into those that appeared to be the products of metasomatic alteration of jadeitite distinguished by calcic pyroxene relics and secondary actinolite and those which did not show these features and typically contained phengite and perhaps zircon, verging into the albite-mica rock suite. In particular the quartz-bearing varieties are mineralogically not much different from trondhjemite and tonalite (sometimes grouped as plagiogranite in an ophiolitic context). It is important, therefore, to differentiate metasomatic or fluid-crystallization albitites from trondhjemites or meta-trondhjemites. At least eight samples are possibly metasomatic: MVE06-4-3\&4, MVE07B-17-2, MVJ90-25-2, MVJ84-12-1, MVJ8424-2, and MVE07B-5-1\&3 based on mineralogy (Table 1); these represent the western half of the occurrences. Of the other five analyzed here, MVJ90-4-2 had an occurrence which could have been either a dike or a vein (no apparent features distinctive of either origin) and texture (medium-fine equigranular without foliation or primary veins) that led to a suspicion that it may have had an igneous origin. However, it contains considerable zoisite; whether this is of metasomatic or metamorphic origin is not clear.

We compare the trace-element composition of this group of rocks in Figures 7 and 8 with several examples of the igneous rocks from the TTD grouping, represented by data from the Lesser Antilles (Neill et al., 2010), Semail ophiolite (Coleman and Donato, 1979), and suprasubduction trondhjemites from the Elder Creek ophiolite, California (Shervais, 2008). These TTDs are distinctive for their N-MORB-like REE patterns. Most of the albitites show depletion in REE by at least an order of magnitude from TTDs, N-MORB or sediment, particularly the group from the La Palmilla area. This difference argues for fluid crystallization for the rock or its protolith. The potential trondhjemite or meta-trondhjemite (MVJ90-4-2) does have the REE signature most similar, although still slightly less enriched than that of a TTD; 
zoisite is the likely REE carrier. Three other rocks from a locality in the western area (MVE06-4$1 \& 3 \& 4)$ are also not greatly different in this comparison. Sample MVJ90-4-2 is enriched in $\mathrm{Pb}$ but not LILE, whereas the other three samples are generally more LILE enriched, particularly in Ba. Among the HFSE elements most TTDs have elevated Th/U (2.4 to 6.2; e.g., Coleman and Donato, 1979; Neill et al., 2010; Shervais, 2008) and Zr/Hf (36 to 323), whereas the albitites have subchondritic Th/U (0.4 to 2.8) and Zr/Hf (15 to 32, except MVJ90-4-2 (44) and MVR0726F (37)). A general observation of fluid transport deposition is that Th is less mobile than U, so this feature may provide support for an interpretation that all of these albitites are either fluid crystallized or metasomatized products of fluid-precipitated protoliths (i.e., jadeitite).

Another source of TTDs that can be compared are derived from intra-slab melting or at least melting of fragments incorporated into mélange portion of the subduction channel, as exemplified by interpretations of them in the Sierra del Convento mélange, eastern Cuba (Lázaro and García-Castro, 2008; Blanco-Quintero et al. 2011; Lázaro et al. 2011). Four examples interpreted as trondhjemites that span the range reported from the Sierra del Convento are included in Figures 7 and 8. They express a much broader range of REE trends, with generally lower normalized values than the other TTDs and perhaps a greater relative HREE depletion. A few of them show a strong Ba enrichment that is ascribed to late fluid infiltration that, as in other aspects of the rocks discussed in this manuscript, likely reflect a sediment signature. In terms of the HFSE, these trondhjemites are reported to have Th/U from 0.88 to 1.96 and $\mathrm{Zr} / \mathrm{Hf}$ from 48 to 776. Although the $\mathrm{Th} / \mathrm{U}$ values are comparable to those in the albitites, $\mathrm{Zr} / \mathrm{Hf}$ values are vastly elevated. Whereas this is a comparison worth evaluating, both the context for the high-T slaboriginated melts and the distinctly different $\mathrm{Zr} / \mathrm{Hf}$ makes them an unlikely protolith for albitites from Guatemala, and probably not for the possible meta-trondhjemite (MVJ90-4-2). 


\subsection{Phengite mica rocks}

These rocks are a distinctive type with no recognizable protolith. The combination of extreme Ba enrichment and compositional zoning patterns, typically rhythmic, of phengite grains (Harlow, 1995) argue for direct precipitation from a hydrous fluid. Recent boron isotopic analysis (Martin et al., 2013, 2015) has shown mostly negative $\delta^{11} \mathrm{~B}$ for all micas from these HP/LT suites, consistent with crystallization from a fractionated dehydration fluid and not an igneous origin. These rocks suggest an extreme example of LILE enrichment found in late-stage to retrograde alteration of HP/LT lithologies in subduction systems discussed by Sorensen et al. (1997), with the LILE source interpreted as subducted sediment. This source would also enhance the contribution to the signature of lighter boron. However, older AOC will be enriched in $\mathrm{K}_{2} \mathrm{O}$ due to formation of $\mathrm{K}$-bearing alteration minerals (generally clays) and provide an additional source of $\mathrm{K}$ in the subduction channel (Jarrard, 2003) but supply heavier boron (Ishikawa and Nakamura, 1993). A similar LILE signature to that in mica rocks was described by Simons et al. (2010) in phengite-bearing eclogite from the SMM; the relative contributions to the boron signature suggest either a greater influence of sediment or very strong dehydration fractionation.

The trace-element characteristics of these mica-rich rocks are compared with those of the most comparable samples for another jadeitite-bearing mélange: quartz-muscovite rocks of the Sierra del Convento of eastern Cuba (Lazaro et al. 2011) in Figure 9. The latter are interpreted as hydrothermal precipitates from a mixed source of sedimentary (high Ba), AOC origin (nonradiogenic $\mathrm{Pb}$ ) and differentiation of trondhjemitic melts. Comparison shows some similarity of MVR07-26F with one Qz-Ms rock, but otherwise there is a large difference in the higher Th and $\mathrm{U}$ concentration and low $\mathrm{Zr}$ and $\mathrm{Hf}$ concentrations of the Cuban samples compared to those from 
Guatemala. This may suggest a difference in the mix of sediment and AOC in the sources or an absence of evolved igneous fluid in the Guatemalan origins, consistent with the difference between interpretations for Guatemala and Sierra del Convento rock suites..

\subsection{What controls whole rock composition?}

If both P-type and R-type jadeitite are largely the result of open system crystallization in the presence of fluid, then they are dominantly the response to super-saturation of the fluid in the minerals that crystallize. Differences in rock composition are thus controlled by the fluid composition and the saturation surface of that fluid during precipitation. Clearly R-type jadeitites may retain a fraction of their initial compositional identity, to the extent that there are relics of the original mineralogy and that metasomatism actually mixes the protolith components with the fluid precipitates. In the case of P-type jadeitites (and some of the related rock types considered here), most element abundances are governed by the fluid or fluids; however, it is possible that some vestiges of the wall rock of a vein or refractory minerals as the only vestiges of a protolith can be found in the vein rock interpreted as totally P-type. That all are not manifestations of veins in serpentinizing ultramafic host but still in a serpentinite mélange is somewhat a reflection of the tectonized and dismembered aspect of jadeitite occurrences. The rare examples of chromite in omphacitite (Harlow and Olds, 1987) are a clear example of relicts from an ultramafic host. The amphibole carapace around jadeitite veins of jadeitite from Myanmar (Shi et al., 2012; Harlow et al., 2014) have been interpreted as a reaction product with serpentinite host and so is another example. As has been argued above, the saturation of the major components of the minerals in the rocks, such as pyroxene, will then exert a potentially large effect on the trace elements that can or cannot enter the crystallizing mineral's crystal 
structure. However, one must also look to the fluid, its source and evolution to interpret the rocks composition.

\subsection{Fluid composition}

Subduction channel fluids are largely derived from dehydration reactions in the downgoing slab. Experiments by Manning $(1998,2004)$ have shown that the blueschist to eclogite transition produces fluids enriched not only in silica and $\mathrm{Na}$ but also in $\mathrm{Al}$. It is suggested that ultramafic rocks from the over-riding mantle can react with excess silica in the fluid to saturate a NaAl-silicate phase rather than quartz. Wohlers et al. (2011) have investigated the solubility of albite and jadeite in $\mathrm{H}_{2} \mathrm{O}$ in the presence of paragonite and quartz at 500 and $600{ }^{\circ} \mathrm{C}$ and $1-2.25$ $\mathrm{GPa}$, appropriate to subduction channels. On the univariant curve $\mathrm{Jd}+\mathrm{Qz}=\mathrm{Ab}$, the total dissolved solid in fluid is $10.3 \mathrm{wt} . \%$ at $600{ }^{\circ} \mathrm{C}$ and $3.3 \mathrm{wt} . \%$ at $500{ }^{\circ} \mathrm{C}$. The concentrations fall off both with decreasing $\mathrm{T}$ and any change in $\mathrm{P}$ (the enriched zone is along the reaction curve approaching melting). In comparison with the range of PT conditions interpreted for jadeitites from the NMM $\left(350{ }^{\circ} \mathrm{C}\right.$ at $0.6 \mathrm{GPa}$ to $500{ }^{\circ} \mathrm{C}$ at $\left.1.4 \mathrm{GPa}\right)$ and the $\mathrm{SMM}\left(350{ }^{\circ} \mathrm{C} @ 1.2 \mathrm{GPa}\right.$ to $450{ }^{\circ} \mathrm{C} @ 2.0$ GPa: Harlow et al., 2011 for both NMM and SMM), the bulk solute (Na-Al-Si-OH) would be from $\sim 0.1$ to $\sim 2.5 \%$ for the NMM and from $\sim 1$ to $\sim 3.5$ wt. $\%$ for the SMM in a system free of other solutes, such as $\mathrm{Cl}$. Their experiments interpret $\mathrm{pH}$ as being mildly alkaline (5.9- 6.4 at $500{ }^{\circ} \mathrm{C}$ where $\log K$ for $\mathrm{H}_{2} \mathrm{O}$ dissociation is extrapolated to $\sim-8$ at $1.4 \mathrm{GPa}$ ). Extreme solubilities observed in their experiments would not appear to be relevant in the Guatemalan jadeitite system except at higher temperatures $\left(>450{ }^{\circ} \mathrm{C}\right)$, so jadeitites with lower temperature, such as in Guatemala (see Harlow et al., 2015), likely indicate modest fluid saturations with sufficient volume over time to produce large quantities of vein crystallization. Wohlers et al. (2011) note that a fluid ascending isothermally will dissolve components until reaching the $\mathrm{Ab}-$ 
$\mathrm{Jd}-\mathrm{Qz}$ equilibrium at which point crystallization will occur. This is likely to be the characteristic for the fluid rising in the mobile channel at the boundary between the subducting slab and overlying mantle wedge, suggesting crystallization may occur in the boundary area although evidence for this has not been substantiated in Guatemala. Fluid penetration into ultramafic blocks in the channel should tend to increase jadeite saturation and decrease silica activity due to serpentinization and may not represent an up-T trajectory. Fluid entering the mantle wedge ultramafic proper presumably will follow an up-T trajectory with the competing effects of Trelated under saturation versus saturation from serpentinization. The general context of jadeitite in serpentinite, whether channel blocks or mantle wedge clearly implies the importance of a fluid reaction with ultramafic rocks.

With the context of a subduction channel origin, the properties of $\mathrm{H}_{2} \mathrm{O}$ at $\mathrm{HP} / \mathrm{LT}$ and the amount of fluid available for transport must play an important role in jadeitite formation. The solute carrying capacity of hydrous fluid changes with conditions as both the dipole moment and dielectric constants of $\mathrm{H}_{2} \mathrm{O}$ change. $\mathrm{H}_{2} \mathrm{O}$ transforms from a dominantly polar solvent to an ionic solvent upon increasing $P$ (e.g., Pan et al., 2013; Galvez et al., 2013; Angiboust et al., 2012) increasing the solubility of many solids. As pointed out by Wohlers et al. (2011), an alkaline fluid enhances solubilities of many elements, including HFSE, probably enhancing the solubility of the least mobile elements (see below). The amount of water expelled by dehydration of the subducting slab is the other important factor. Main contributors in the AOC and sediments at conditions above greenschist facies are primarily amphiboles with 1-2 wt. $\% \mathrm{H}_{2} \mathrm{O}$ and phyllosilicates with up to $12 \mathrm{wt} . \%$, and if serpentinized seafloor is included the $\mathrm{H}_{2} \mathrm{O}$ content is that of the phyllosilicate (antigorite). Even at a fraction of $1 \mathrm{wt} \% \mathrm{H}_{2} \mathrm{O}$ being liberated at the blueschist-to-eclogite facies transition, a vast amount of fluid is produced at a steady pace (even 
if it travels in pulses) as pointed out by many (e.g., Manning, 2004; Jarrard, 2003; Hacker, 2008). So, high solute capacity of the fluid may not be necessary, rather the alkaline conditions of deep fluid in the altered oceanic crust yields a "jadeitic solute" and sufficient sedimentary remnants boost elements such as Ba to yield a typical jadeitite.

\subsection{Trace element transport}

This examination of vein rock compositions points out that, in addition to the expected content of LILE, some HFSE (such as Zr and Hf) are enriched in comparison with N-MORB. There are studies that support the interpretation that jadeite-albite precipitating fluids will enhance $\mathrm{Zr}$ (and probably other HFSE elements) solubility. There is a positive effect of alkalinity and $\mathrm{Na}$ and $\mathrm{Si}$ concentration (probably negatively with $\mathrm{Al}$ ), although there is some disagreement about the role of alkali zircono-silicate complexing (Ayers et al., 2012, Wilke et al., 2012; Bernini et al., 2013). Experiments suggest $\mathrm{Zr}$ concentrations in channel dehydrating fluids are from 1-4 $\mu \mathrm{g} / \mathrm{g}$ (Bernini et al., 2013); concentrations in Na-Si rich fluids at $\mathrm{P}$ and $\mathrm{T}$ consistent with jadeitite stability can arguably be much higher (perhaps as high as $100 \mu \mathrm{g} / \mathrm{g}$; Wilke et al., 2012). The latter authors suggest that Ti and other HFSE are stabilized by the same alkali HFSEsilicate complexing mechanism, and, thus, they should be both dissolved and transported by the same kind of fluid invoked in our model for crystallizing fluids for jadeitite and similar vein rocks. If the transport of HFSE is equally efficient in the fluids that crystallized both NMM and SMM jadeitites, it would suggest that the difference in Ti content is related to what the fluid "saw" prior to jadeitite precipitation, i.e., more metabasite in the SMM. This also appears to be reflected in the jadeitite bulk $\mathrm{TiO}_{2}$ and $\mathrm{Zr}$ contents (Figure 2) that do appear to be correlated in SMM jadeitites, although $\mathrm{Zr}$ is relatively more enriched than in any of the subduction channel source rocks. On the other hand, NMM jadeitites (with generally much lower abundances of both 
elements) vary widely in $\mathrm{TiO}_{2} / \mathrm{Zr}$ ratios and the two elements are perhaps anti-correlated among La Palmilla samples. It is not clear whether source, solubility, or some other factor controls this relationship. If dehydration fluids can carry up to several wt.\% of dissolved solutes, the required carrying capacity for the trace elements, which vary from maxima of $\sim 5000 \mu \mathrm{g} / \mathrm{g}$ for Ba, 500 $\mu \mathrm{g} / \mathrm{g} \mathrm{Zr}$ to $7 \mu \mathrm{g} / \mathrm{g}$ for $\mathrm{Nb}$ in the precipitate, does not need to be large, just that the fluid to precipitated rock mass ratio must be large (probably well in excess of 100 based on fluid/mineral partitioning compiled in Sorensen et al., 2006). Jadeitites are witnesses of this transport process, but they do not contain significant amounts of volatiles. Hence, the fluids do not terminate with the crystallization of jadeitite but migrate onwards to deliver volatiles to the mantle wedge and likely continue to feed flux melting processes at higher temperatures.

\section{Conclusions}

The suite of rocks presented here associated with jadeitite from the NMM and SMM of Guatemala are interpreted primarily as precipitates from hydrous fluids within the subduction channel transiting into ultramafic units or modifications thereof in the case of some albitites. Some albitites may represent meta-trondhjemites. The whole rock data presented here demonstrate some consistencies as well as considerable diversity among rock types and local sources in this group. The chemical signatures of jadeitites, beyond their major-elements, are largely controlled by the crystal chemistry of jadeititic pyroxene, albite and mica, which typically manifest enrichment of LILEs including $\mathrm{Cs}$, $\mathrm{Ba}$, and $\mathrm{Pb}$ (but not $\mathrm{K}$ and $\mathrm{Sr}$ ), particularly in the NMM, enrichment of Th, U, Zr and Hf compared to HREE, and much more variable REE contents. Although fewer in number than NMM jadeitites, SMM jadeitites are more uniform in trace element compositions, more enriched in $\mathrm{Ba}$ and $\mathrm{Cs}$, with REE showing a somewhat concave shape with higher LREE than Lu. These trace-element patterns mimic, to a large extent, 
global sediment (GLOSS), Antillean sediment, except for the REE which are much more variable at different degrees of depletion. If these patterns represent precipitated solute, then the trace elements are transported relatively uniformly from such a subduction channel source while skewing the major elements toward jadeite-like composition. The best potential indicator of fluid precipitation may be the trend toward low $\mathrm{Th} / \mathrm{U}$ for most samples, an indication of the lower solubility of Th compared to $\mathrm{U}$ in hydrous fluids. Finally, there is a general difference in the compositions of jadeitites from the NMM versus the SMM which may point to a combination of source differences for the solutes or rocks that contributed to their formation as well as the distinctly different conditions of PT recorded in the two mélanges. However, the variation in rock compositions, particularly in the NMM, suggests a complex mixture of fluid sources or pathways through a compositionally diverse system in a subduction channel, as originally suggested by Sorensen et al. (2006). Perhaps a variation on this theme is distinctly different local conditions of crystallization (P, T, and fluid saturation) for the rocks. In the context of the working model that jadeitites and related rocks crystallized within fractured ultramafics derived from the mantle wedge above a subduction channel, the lack of signature for an ultramafic contribution to most of the rocks suggests its main contribution to the formation of these fluid crystallization products was its thermal and absorptive capacity.

\section{Acknowledgments and Data}

This research was supported by grants from the US National Science Foundation (EAR 0309116 and 1119403) awarded to G.E.H. This manuscript was reviewed and improved by the reviews of Antonio García-Casco and an anonymous reviewer. We thank jadeitite colleagues Sorena Sorensen, Virginia Sisson, Hannes Brueckner, Tatsuki Tsujimori, and Céline Martin for support and helpful feedback. 
A full spreadsheet of the whole rock analyses presented in this paper are available as supplementary Appendix A. (Upon acceptance of this manuscript, rock information will be loaded into MetPetDB. Other information is available from the first author.)

\section{References}

Angiboust, S., Wolf, S., Burov, E., Agard, P., and Yamato, P., 2012. Effect of fluid circulation on subduction interface tectonic processes: Insights from thermo-mechanical numerical modelling. Earth and Planetary Science Letters 357-358, 238-248, doi:10.1016/j.eps1.2012.09.012.

Ayers, J. C., Zhang, L., Luo, Y., Peters, T. J., 2012, Zircon solubility in alkaline aqueous fluids at upper crustal conditions. Geochimica et Cosmochimica Acta 96: 18-28, doi:10.1016/j.gca.2012.08.027.

Bali, E., Audétat, A., Keppler, H., 2011. The mobility of U and Th in subduction zone fluids; an indicator of oxygen fugacity and fluid salinity. Contributions to Mineralogy and Petrology 161.4, 597-613, doi:10.1007/s00410-010-0552-9.

Bernini, D., Audétat, A., Dolejs, D., Keppler, H., 2013. Zircon Solubility in Aqueous Fluids at High Temperatures and Pressures. Geochimica et Cosmochimica Acta 119, 178-187, doi:10.1016/j.gca.2013.05.018.

Blanco-Quintero, I.F., Lázaro, C., García-Casco, Proenza, J.A., and Rojas-Agramonte, Y. (2011) Barium-rich fluids and melts in a subduction environment (La Corea and Sierra del Convento me'langes, eastern Cuba). Contributions to Mineralogy and Petrology 162, 395-413. DOI 10.1007/s00410-010-0603-2. 
Bonnet, G., Flores, K.E., Martin, C., Harlow, G.E., 2014. Unraveling the polymetamorphic history of garnet-bearing metabasites: Insights from the North Motagua Mélange (Guatemala Suture Zone). Abstract V43B-4882 presented at Fall Meeting, AGU, San Francisco, California, 15-19 Dec.

Bröcker, M., Enders, M., 2001. Unusual bulk-rock compositions in eclogite-facies rocks from Syros and Tinos (Cyclades, Greece); implications for U-Pb zircon geochronology. Chemical Geology 175 (3-4), 581-603.

Brueckner, H.K., Avé Lallemant, H.G., Sisson, V.B., Harlow, G.E., Hemming, S.R., Martens, U., Tsujimori, T., Sorensen, S. S., 2009. Metamorphic reworking of a high pressure-low temperature mélange along the Motagua fault, Guatemala: A record of Necomian and Maastrichtian transpressional tectonics. Earth and Planetary Science Letters 284, 228235, doi:10.1016/j.epsl.2009.04.032.

Chan L.-H., Leeman, W. P., Plank T., 2006. Lithium isotopic composition of marine sediments. Geochemistry, Geophysics Geosystems 7, doi:10.1029/2005GC001202.

Coleman, R.G., Donato, M.M., 1979. Oceanic plagiogranite revisited. In: Barker, F. (Ed.) Trondhjemites, Dacites and Related Rocks. Elsevier, Amsterdam, pp. 149-167.

Compagnoni. R., Rolfo. F., Castelli. D., 2012. Jadeitite from the Monviso meta-ophiolite, western Alps: occurrence and genesis. European Journal of Mineralogy 24, 333-343, doi:10.1127/0935-1221/2011/0023-2164.

Endo, S., Wallis, S.R., Tsuboi, M., Torres de León, R., and Solari, L.A., 2011. Metamorphic evolution of lawsonite eclogites from the southern Motagua fault zone, Guatemala: 
insights from phase equilibria and Raman spectroscopy. Journal of Metamorphic Geology 30.2, 143-164.

Flores, K., Harlow, G.E. Martens, U., Brueckner, H.K., Pearson, N., 2013. Jadeitite formed during subduction: Zircon geochronology constraints for two different tectonic events in the Guatemala Suture Zone. Earth and Planetary Science Letters 371-372, 67-81, doi:10.1016/j.epsl.2013.04.015.

Flores, K.E., Hemming, S., Harlow, G.E., Cai., Y., Bonnet, G., Martin, C., Brueckner, H.K., 2014. Metamorphic evolution of high-pressure-low-temperature rocks from the northern section of the Guatemala Suture Zone: PTt paths and tectonic implications, Abstract V43B-4883 presented at Fall Meeting, AGU, San Francisco, California, 15-19 Dec.

Fu, B. Valley, J.W., Kita, N.T., Spicuzza, M.J., Paton, C., Tsujimori, T., Bröcker, M., Harlow, G.E., 2010. Origin of zircons in jadeitite. Contributions to Mineralogy and Petrology 159, 769-780, doi:10.1007/s00410-009-0453-y.

Galvez, M. E., Martinez, I., Beyssac, O., Benzerara, K., Agrinier, P., Assayag, N., 2013, Metasomatism and graphite formation at a lithological interface in Malaspina (Alpine Corsica, France). Contributions to Mineralogy and Petrology 166 (6), 1687-1708, doi:10.1007/s00410-013-0949-3.

Gerya, T.V., Stoeckhert, B., Perchuk, A. L., 2002. Exhumation of high-pressure metamorphic rocks in a subduction channel; a numerical simulation. Tectonics $21,6-1-6-19$, doi:10.1029/2002TC001406

Hacker, B.R., 2008. $\mathrm{H}_{2} \mathrm{O}$ subduction beyond arcs. Geochemistry, Geophysics, Geosystems 9.3, Q03001, doi:10.1029/2007GC001707. 
Harlow, G.E., 1994. Jadeitites, albitites and related rocks from the Motagua Fault Zone, Guatemala. Journal of Metamorphic Geology 12, 49-68.

Harlow, G.E., 1995. Crystal chemistry of barian enrichment in micas from metasomatized inclusions in serpentinite, Motagua Valley, Guatemala. European Journal of Mineralogy, 7, 775-789.

Harlow, G.E., Hemming, S.R., Avé Lallemant, H.G., Sisson, V.B., Sorensen, S.S., 2004a. Two HP/LT Serpentine-Matrix Melange Belts, Motagua Fault Zone, Guatemala: A Record of Aptian and Maastrichtian Collisions. Geology 32, 17-20, doi:10.1130/G19990.1.

Harlow, G.E., Olds E.P., 1987. Observations on terrestrial ureyite and ureyitic pyroxene. American Mineralogist, 72, 126-136.

Harlow, G.E., Quinn, E.P., Rossman, G.R., Rohtert, W.R., 2004b, Blue omphacite from Guatemala. Gems and Gemology 40, 68-70.

Harlow, G.E., Shi, G., 2011. An LA-ICPMS study of lavender jadeite from Burma, Guatemala and Japan (abstract). GIA Symposium 2011, Gems \& Gemology 47(2), 116-117.

Harlow, G.E., Sisson, V.B., Sorensen, S.S., 2011. Jadeitite from Guatemala: Distinctions among multiple occurrences. Geologica Acta 9 (3), 363-387, doi:10.1344/105.000001694.

Harlow, G.E., Sisson, V.B., Tsujimori, T., Sorensen, S.S., Brueckner, H.K., 2008. P-T conditions of eclogite / garnet-amphibolite from serpentinite mélanges along the Motagua fault zone, Guatemala. Annual Meeting, Geological Society of America Abstracts with Programs $40(6), 452$ 
Harlow, G.E., Sorensen, S.S., Sisson, V.B., 2014. Jade. In: Groat, L.A. (Ed.), The Geology of Gem Deposits, Short Course Handbook Series 44, Mineralogical Association of Canada, Quebec, pp. $305-374$.

Harlow, G.E., Tsujimori, T., Sorensen, S.S., 2012. Introduction to jadeitites: New occurrences, new data and implications for subduction zone fluids. European Journal of Mineralogy, 24, 197-198, doi: 10.1127/0935-1221/2012/0024-2196

Harlow, G.E., Tsujimori, T., Sorensen, S.S., 2015. Jadeitites and plate tectonics. Annual Reviews in Earth and Planetary Sciences 43, 105-138, doi:10.1146/annurev-earth-060614-105215.

Hughes, R.W., Galibert, O., Bosshart, G., Ward, F., Oo, T., Smith, M. Sun, T.T., Harlow, G.E., 2000. Burmese jade: The inscrutable gem. Gems and Gemology 36 (1), 2-26.

Ishikawa, T., Nakamura, E., 1993. Boron isotope systematics of marine sediments. Earth and Planetary Science Letters 117, 567-580.

Jarrard, R.D., 2003. Subduction fluxes of water, carbon dioxide, chlorine, and potassium, Geochemistry, Geophysics, Geosystems 4(5), 8905, doi:10.1029/2002GC000392, 2003.

Klein, E.M. (2003) Geochemistry of the igneous oceanic crust. In: Holland, H.D.; Turekian, K.K. (Eds.) Treatise on Geochemistry: Vol. 3: The Crust, Elsevier, pp. 443-463.

Lázaro, C., Blanco-Quintero, I.F., Marchesi, C., Bosch, D., Rojas-Argramonte, Y., and GarcíaCasco (2011) The imprint of subduction fluids on subducted MORB-derived melts (Sierra del Convento Mélange, Cuba). Lithos 126, 341-354. doi:10.1016/j.lithos.2011.07.011. 
Lázaro, C., and García-Casco, A. (2008) Geochemical and Sr-Nd isotope signatures of pristine slab melts and their residues (Sierra del Convento mélange, eastern Cuba). Chemical Geology 255, 120-133. doi:10.1016/j.chemgeo.2008.06.017

Manning, C.E., 1998. Fluid composition at the blueschist-eclogite transition in the model system $\mathrm{Na}_{2} \mathrm{O}-\mathrm{MgO}-\mathrm{Al}_{2} \mathrm{O}_{3}-\mathrm{SiO}_{2}-\mathrm{H}_{2} \mathrm{O}-\mathrm{HCl}$. Schweizerische Mineralogische und Petrographische Mitteilungen 78 (2), 225-242.

Manning, C.E. 2004. The chemistry of subduction-zone fluids. Earth and Planetary Science Letters 223, 1-16, doi:10.1016/j.eps1.2004.04.030.

Martin, C., Ponzevera, E., Harlow, G.E., 2013. Boron isotopic signatures in phengite from the Guatemalan HP rocks, Abstract Volume, $10^{\text {th }}$ International Eclogite Conference, September 2-10, 2013 Courmayeur, Italy, p. 82.

Martin, C., Flores, K.E., Harlow, G.E., 2015. Boron isotopes discrimination for subductionrelated serpentinites: Example of the Guatemala Suture Zone. Abstracts with Programs, Annual Meeting, Geological Society of America, 47 (7), 434.

McDonough, W.F., Sun, S.-S. (1995) The composition of the Earth. Chemical Geology 120, 223-253.

Miyajima, H. (1999) Bulk chemistry of jades from -the ltoigawa - Ohmi district. Abstract volume of the Annual meeting of the Japanese Association of Mineralogists, Petrologists, and Economic Geologists, p. 170

Morishita, T., Arai, S., Ishida, Y., 2007. Trace element compositions of jadeite (+omphacite) in jadeitites from the Itoigawa-Ohmi district, Japan: Implications for fluid processes in subduction zones. Island Arc 16 (1), 40-56, doi:10.1111/j.1440-1738.2007.00557.x. 
Neill, I., Gibbs, J.A., Hastie, A.R., Kerr, A.C., 2010. Origin of the volcanic complexes of La Désirade, Lesser Antilles: Implications for tectonic reconstruction of the Late Jurassic to Cretaceous Pacific-proto Caribbean margin. Lithos 120, 407-420, doi:10.1016/j.lithos.2010.08.026.

Oberhänsli, R., Bousquet, R., Moinzadeh, H., Moazzen M, Arvin, M., 2007. The field of stability of blue jadeite: A new occurrence of jadeitite from Sorkhan, Iran, as a case study. The Canadian Mineralogist 45, 1705-1713, doi:10.3749/canmin.45.6.1501.

Pan, D., Spanu, L., Harrison, B., Sverjensky, D.A., Galli, G., 2013. Dielectric properties of water under extreme conditions and transport of carbonates in the deep Earth. Proceedings of the National Academy of Science 1221581110, doi:10.1073/pnas.1221581110

Plank, T., Langmuir, C.H., 1998. The chemical composition of subducting sediment and its consequences for the crust and mantle. Chemical Geology 145, 325-394.

Schertl, H-P., Maresch, W.V., Stanek, K.P., Hertwig, A., Krebs, M., Baese, R., and Sergeev, S.S. 2012. New occurrences of jadeitite, jadeite quartzite and jadeite-lawsonite quartzite in the Dominican Republic, Hispaniola: petrological and geochronological overview. European Journal of Mineralogy, 24, 199-216, doi: 10.1127/0935-1221/2012/0024-2201

Shannon, R.D. (1976) Revised effective ionic radii and systematic studies of interatomic distances in halides and chalcogenides. Acta Crystallographica A32, 751-757.

Shervais, J.W., 2008. Tonalites, trondhjemites, and diorites of the Elder Creek ophiolite, California: Low-pressure slab melting and reaction with the mantle wedge. In: Wright, J.E., Shervais, J.W. (Eds.), Ophiolites, Arcs, and Batholiths: A Tribute to Cliff Hopson, 
Geological Society of America Special Paper 438, pp. 113-132, doi:10.1130/2008.2438(03).

Shi, G., Cui, W., Cao, S., Jiang, N., Jian, P., Liu, D., Miao, L., Chu, B., 2008. Ion microprobe zircon U-Pb age and geochemistry of the Myanmar jadeitite. Journal of the Geological Society, London 165, 221-234, doi:10.1144/0016-76492006-119.

Shi, G-H., Harlow, G.E., Wang, J., Wang, J., Ng, E., Wang, X., Cao, S.M., 2012. Mineralogy of jadeitite and related rocks from Myanmar: a review with new data. European Journal of Mineralogy 24, 345-370, doi:10.1127/0935-1221/2012/0024-2190.

Shigeno, M., Mori, Y., Shimada, K., Nishiyama, T., 2012a. Jadeitites with metasomatic zoning from the Nishisonogi metamorphic rocks, western Japan: fluid-tectonic block interaction during exhumation. European Journal of Mineralogy 24, 289-311, doi:10.1127/09351221/2012/0024-2198.

Shigeno, M., Mori, Y., Shimada, K., Nishiyama, T., 2012b. Origin of omphacitites from the Nishisonogi metamorphic rocks, western Kyushu, Japan: Comparison with jadeitites. European Journal of Mineralogy, 24, 247-262, doi:10.1127/0935-1221/2012/0024-2198.

Simons, K.K., Harlow, G.E., Sorensen, S.S., Brueckner, H.K., Goldstein, S.L., Hemming, N.G., Langmuir, C.H., 2010. Lithium isotopes in Guatemala and Franciscan HP-LT rocks: insights into the role of sediment-derived fluids in the mantle wedge. Geochimica et Cosmochimica Acta 74, 3621-3641, doi:10.1016/j.gca.2010.02.033.

Sorensen, S.S., Grossman, J.N. Perfit, M.R., 1997. Phengite-hosted LILE enrichment in eclogite and related rocks: Implications for fluid-mediated mass transfer in subduction zones and arc magma genesis. Journal of Petrology 38, 3-34, doi:10.1093/petrology/38.1.3. 
Sorensen, S.S., Harlow, G.E., Rumble, D. III, 2006. The origin of jadeitite-forming subduction zone fluids: CL-guided SIMS oxygen isotope and trace element evidence. American Mineralogist 91, 979-996, doi:10.2138/am.2006.1949.

Sorensen, S.S., Sisson V.B., Harlow, G.E., Avé Lallemant, H.G., 2010. Element transport and residence sites during subduction zone metasomatism: Evidence from a jadeititeserpentinite contact, Guatemala. International Geology Review, 52 (9), 899-940, doi:10.1080/00206810903211963.

Sun, S.S., McDonough, W.F., 1989. Chemical and isotopic systematics of oceanic basalts: implications for mantle composition and processes. In: Saunders, A.D., Norry, M.J. (Eds.), Magmatism in the Ocean Basins, Geological Society Special Publication 42, Geological Society of London, London, pp. 313-345.

Tsujimori, T., Harlow, G.E., 2012. Petrogenetic relationships between jadeitite and associated high-pressure and low-temperature metamorphic rocks in worldwide jadeitite localities: A review. European Journal of Mineralogy, 24, 371-390, doi:10.1127/09351221/2012/0024-2193.

Tsujimori, T., Sisson, V.B., Liou, J.G., Harlow, G.E., Sorensen, S.S., 2006a. Petrologic characterization of Guatemalan lawsonite eclogite: eclogitization of subducted oceanic crust in a cold subduction zone. In: Hacker, B.R., McClelland, W.C., Liou, J.G. (Eds.), Ultrahigh-pressure Metamorphism: Deep Continental Subduction. Geological Society of America Special Paper 403, pp. 147-168, doi:10.1130/2006.2403(09). 
Tsujimori, T., Sisson, V.B., Liou, J.G., Harlow, G.E., Sorensen, S.S., 2006b. Very lowtemperature record in subduction process: a review of worldwide lawsonite eclogites. Lithos 92 (3-4), 609-624, doi:10.1016/j.lithos.2006.03.054.

Whitney, D.L., Evans, B.W., 2010. Abbreviations for names of rock-forming minerals. American Mineralogist 95, 185-187, doi:10.2138/am.2010.3371.

Wilke, M., Schmidt, C., Dubrail, J., Appel, K., Borchert, M., Kvashnina, K., Manning, C.E., 2012. Zircon solubility and zirconium complexation in $\mathrm{H}_{2} \mathrm{O}+\mathrm{Na}_{2} \mathrm{O}+\mathrm{SiO}_{2} \pm \mathrm{Al}_{2} \mathrm{O}_{3}$ fluids at high pressure and temperature. Earth and Planetary Science Letters 349-350, 1525, doi:10.1016/j.epsl.2012.06.054.

Wohlers, A., Manning, C.E., Thompson, A.B., 2011. Experimental investigation of the solubility of albite and jadeite in $\mathrm{H}_{2} \mathrm{O}$, with paragonite + quartz at 500 and $600{ }^{\circ} \mathrm{C}$ and 1-2.25 GPa. Geochimica et Cosmochimica Acta 75, 2924-2939, doi:10.1016/j.gca.2011.02.028.

Yui, T-F., Maki, K., Usuki, T., Lan, C-Y., Martens, U., Wu, C-M., Wu, T-W., Liou, J.G., 2010. Genesis of Guatemala jadeitite and related fluid characteristics: Insight from zircon. Chemical Geology 270, 45-55, doi:10.1016/j.chemgeo.2009.11.004.

Yui, T-F., Maki, K., Wang, K.L., Lan, C.Y., Usuki, T., Iizuka, Y., Wu, C.M., Wu, T.W., Nishiyama, T., Martens, U., Liou, J.G., Grove, M., 2012. Hf isotope and REE composition of zircon from jadeitite (Tone, Japan and north of the Motagua fault, Guatemala): implications on jadeitite genesis and possible protoliths. European Journal of Mineralogy 24, 263-275, doi:10.1127/0935-1221/2011/0023-2127. 
Yui, T-F., Fukoyama, M., Iizuka, Y., Wu, C-M., Wu, T-W., Liou, J.G. Grove, M., 2013. Is Myanmar jadeitite of Jurassic age? A result from incompletely recrystallized inherited zircon. Lithos 160-161, 268-282, doi:10.1016/j.lithos.2012.12.011.

Figure 1. A simplified geotectonic map of the central Guatemala Suture Zone (GSZ) showing distribution of key units such as: serpentinite mélanges, ophiolites and oceanic crust sequences. Abbreviations for the main units: Sierra de Santa Cruz ophiolite (SSC), Baja Verapaz ophiolite (BVP), Juan de Paz ophiolite (JPZ), North Motagua Mélange (NMM), and South Motagua Mélange (SMM). Rock location symbols show general locations for these samples, with symbol colors coded to the groupings used in this study: open symbols in the NMM - black for western, brown for Manzanal, blue for Sierra de Las Minas, green for La Palmilla, red for Panaluya, and orange for eastern; in the SMM - purple for Carrizal Grande, dark red for La Ceiba, and dark green for La Ensenada and pink for Río El Tambor alluvials (although probably derived from Carrizal Grande and La Ceiba area sources).

Figure 2. Binary major oxide plots $\left(\mathrm{SiO}_{2}, \mathrm{Al}_{2} \mathrm{O}_{3}, \mathrm{CaO}, \mathrm{Na}_{2} \mathrm{O}\right.$, and $\mathrm{K}_{2} \mathrm{O}$ versus $\left.\mathrm{MgO}\right)$ and $\mathrm{TiO}_{2}$ versus $\mathrm{Zr}$ for all samples in this study plus values for global subducting sediments, Antillean terrigenous sediment (GLOSS and Anti. Terr. - Plank and Langmuir, 1998) and N-MORB (McDonough and Sun, 1989 and Klein, 2003) for comparison.

Figure 3. Rare earth element (REE) plots of jadeitite whole-rock compositions normalized to primitive upper mantle (PUM: McDonough and Sun, 1995), organized by areas for both NMM and SMM. Values for the detection limits are plotted and those concentrations below the detection limit are plotted at that value rather than not being plotted at all. This procedure is used 
in the rest of the trace-element plots. For comparison patterns are presented for global N-MORB (McDonough and Sun, 1989 and Klein, 2003) subducting sediment (GLOSS: Plank and Langmuir, 1998) and Ocean Island Basalt (OIB: Sun and McDonough, 1989).

Figure 4. Trace-element "spidergram" plots for jadeitite whole rock compositions normalized to N-MORB (McDonough and Sun, 1989 and Klein, 2003), organized by areas for both NMM and SMM. Elements are organized in increasing order of field strength (ionic charge/ionic radius) based on six-fold ionic radii, thus the large ion lithophile elements (LILE), including K, are on the left side and the high field strength elements (HFSE) are to the right. For comparison patterns are presented for global subducting sediment and Antillean terrigenous sediment (GLOSS and Antil. Terrig.: Plank and Langmuir, 1998).

Figure 5. Rare earth element (REE) plots of omphacitite whole-rock compositions normalized to primitive upper mantle, organized by areas for both NMM (top) and SMM (bottom), as in Fig. 3.

Figure 6. Trace-element "spidergram" plots for omphacitite whole rock compositions normalized to N-MORB, organized by areas for both NMM and SMM, as in Fig. 4.

Figure 7. Rare earth element (REE) plots of albitite whole-rock compositions normalized to primitive upper mantle (PUM), as in Fig. 3. Patterns for trondhjemite (Trondhjemite 1: Neill et al., (2010) and EC176-1: Shervais (2008)), tonalite (EC218-2A: Shervais (2008)), plagiogranite (Coleman and Donato, 1979), and the slab derived meta-trondhjemites in the mélange from the Sierra del Convento in Cuba (CV201a: Blanco-Quintero et al., 2011; CU-72 and SC-20: Lázaro et al., 2011; and CV227b: Lázaro and García-Casco, 2008) are plotted for comparison. 
Figure 8. Trace-element "spidergram" plots for albitite whole rock compositions normalized to N-MORB, organized by areas for NMM alone, as in Fig. 4. Comparative patterns for trondhjemite and plagiogranite are from the same sources as in Fig. 7.

Figure 9. Rare earth element (REE) and trace-element "spidergram" plots for mica-albite and mica rocks from the NMM of Guatemala, as in Fig. 3 and 4, respectively. Mica-albite rocks are shown with finely dashed lines and the mica rocks with solid lines. For comparison two quartzmuscovite rocks from the mélange from the Sierra del Convento in Cuba (CV53E-II and CV278a-I: Lázaro et al., 2011) are presented.

Figure 10. Trace-element "spidergram" plots for in-situ jadeite and omphacite compositions by LA-ICPMS and SIMS normalized to N-MORB, as in Fig 4, from jadeitites and omphacitites from Itoigawa-Ohmi area, Japan (Morishita et al., 2007; Sorensen et al., 2006), Myanmar (Sorensen et al., 2006; Harlow and Shi, 2011), Guatemala (Sorensen et al., 2006; Harlow \& Shi, 2011; and previously unpublished) and Itmurundy (Sorensen et al., 2006). Among the Morishita et al. (2007) data, L values are for lavender jadeite and W for white jadeite; the Myanmar samples are all from the Jade Mine Tract except CJ values which are from Nansibon, $70 \mathrm{~km}$ further west (see Hughes et al., 2000).

Figure 11. Trace-element "spidergram" plots for whole-rock jadeitite compositions normalized to N-MORB, as in Fig 4. Data are from Myanmar (Shi et al., 2008), Syros and Tinos (Bröcker \& Enders, 2001), Nishisonogi, Japan (Shigeno et al., 2012a), the Western Alps (Compagnoni et al., 2012).

Figure 12. Trace-element "spidergram" plots of compositions for omphacite and jadeiteomphacite from Ohmi-Itoigawa area, Japan (Morishita et al., 2007) and omphacitite from Syros 
and Tinos (Bröcker \& Enders, 2001) and Nishisonogi belt, Japan (Shigeno et al., 2012b) normalized to N-MORB, as in Fig 4.

Table 1. List of samples used in this study organized by geographic location with a brief rock identification and minerals identified in the sample. The relative abundance of a mineral is schematically provided as the number of $\mathrm{X}$ in the table. Identifications included whether they were analyzed (determined) by electron microprobe, X-ray microdiffraction, or optical petrography. Mineral abbreviations are according to Whitney and Evans (2010), except bnl = banalsite, cym $=$ cymrite, ftrm $=$ ferrotaramite, hyl $=$ hyalophane, prs $=$ preiswerkite, and $\mathrm{wm}=$ white mica. 


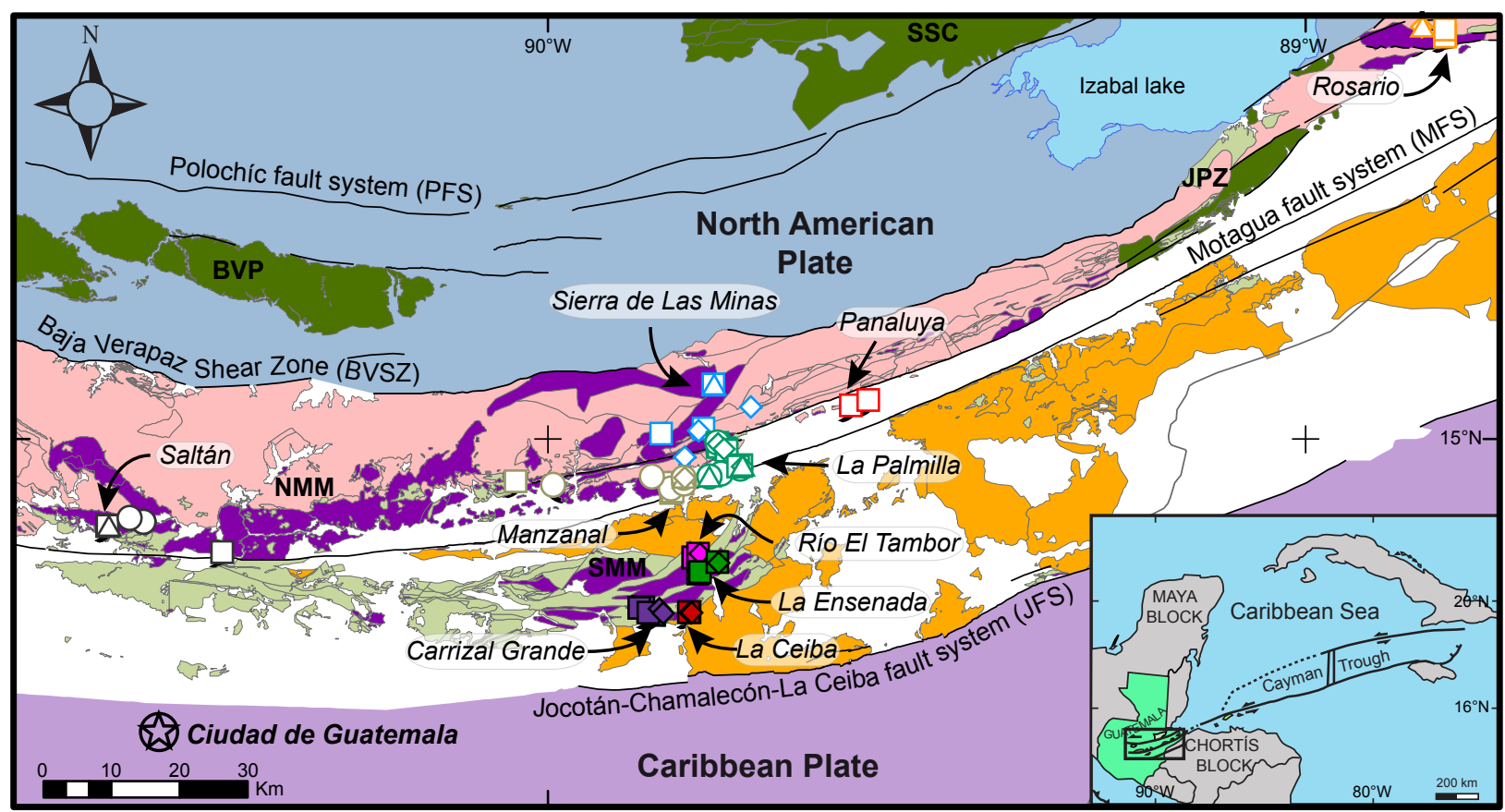

\section{Guatemala Suture Zone}

Passive margin metamorphic sequences

Ophiolite sequences

Serpentinite
mélange $\square$ Volcano-sedimentary

Active margin metamorphic sequences

Maya Block

$\square$ Undifferentiated
overlap sequences

Omphacitite
Main fault

$\bigcirc$ Albitite
Chortís Block

$\bigwedge$ Mica rock 

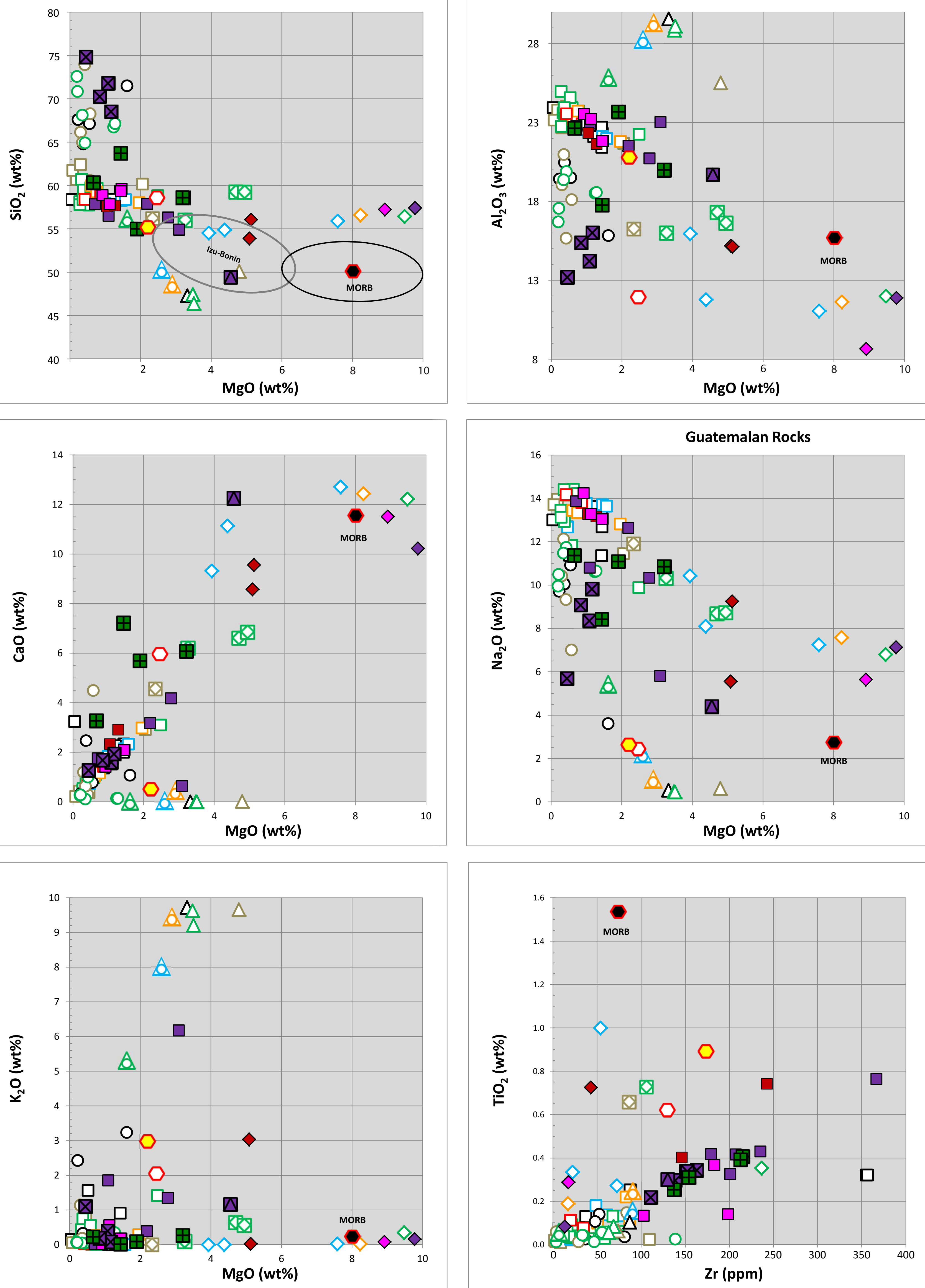

$\square$ Jadeitite $\diamond$ omphacitite $\bigcirc$ Albitite $\triangle$ Mica Rock $\bigotimes$ Jadeite-Omphacitite Q Mica-Albitite $\bigotimes$ Qtz-Jadeitite $\boxplus$ Pmp-Jadeitite $\quad \square$ Lws-Jadeitite NMM (open symbols): Western, Manzanal, Sierra de Las Minas, La Palmilla, Panaluya, Eastern SMM (filled symbols): Carrizal Grande, La Ceiba, La Ensenada, El Tambor 
Figure 3
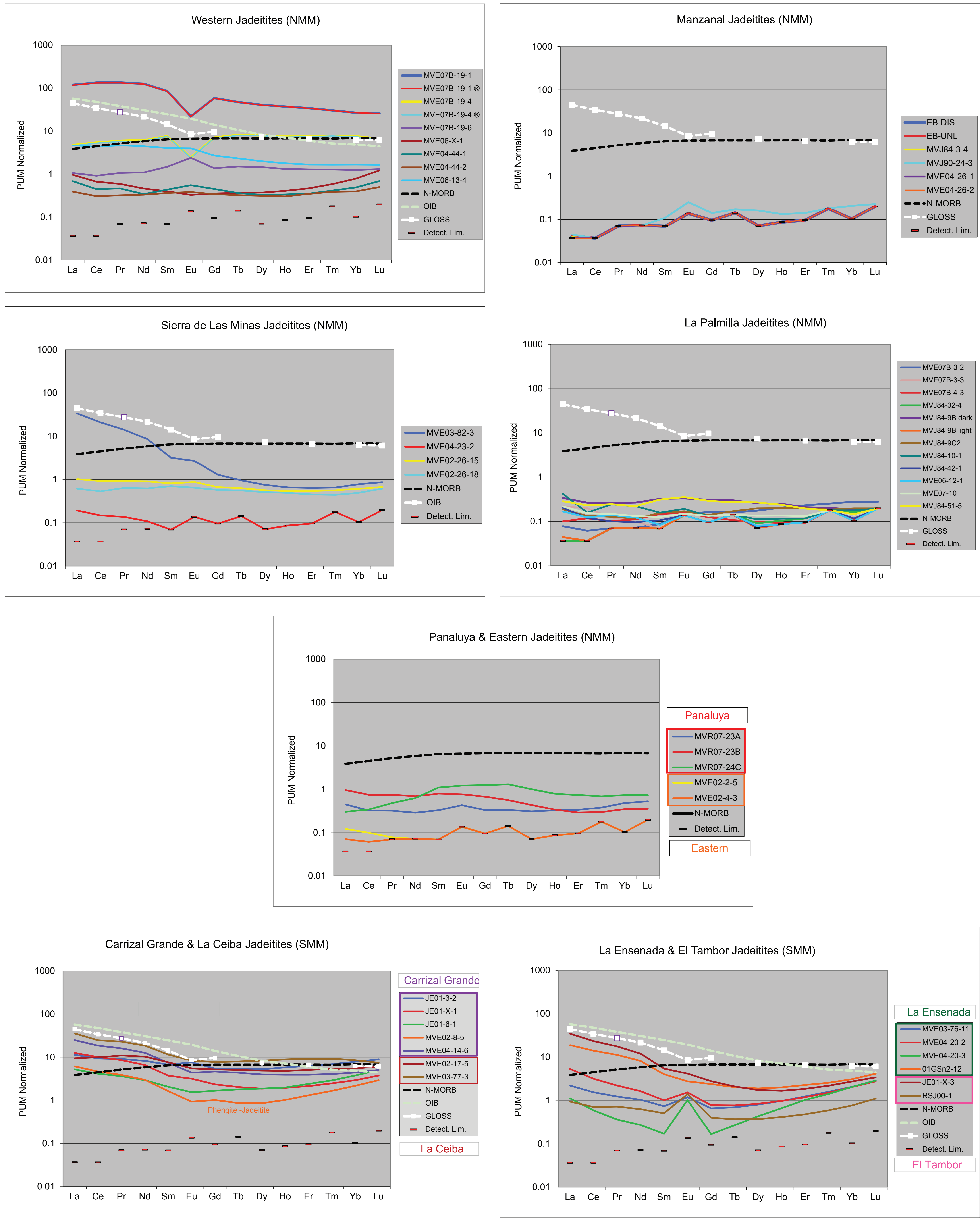
Figure 4
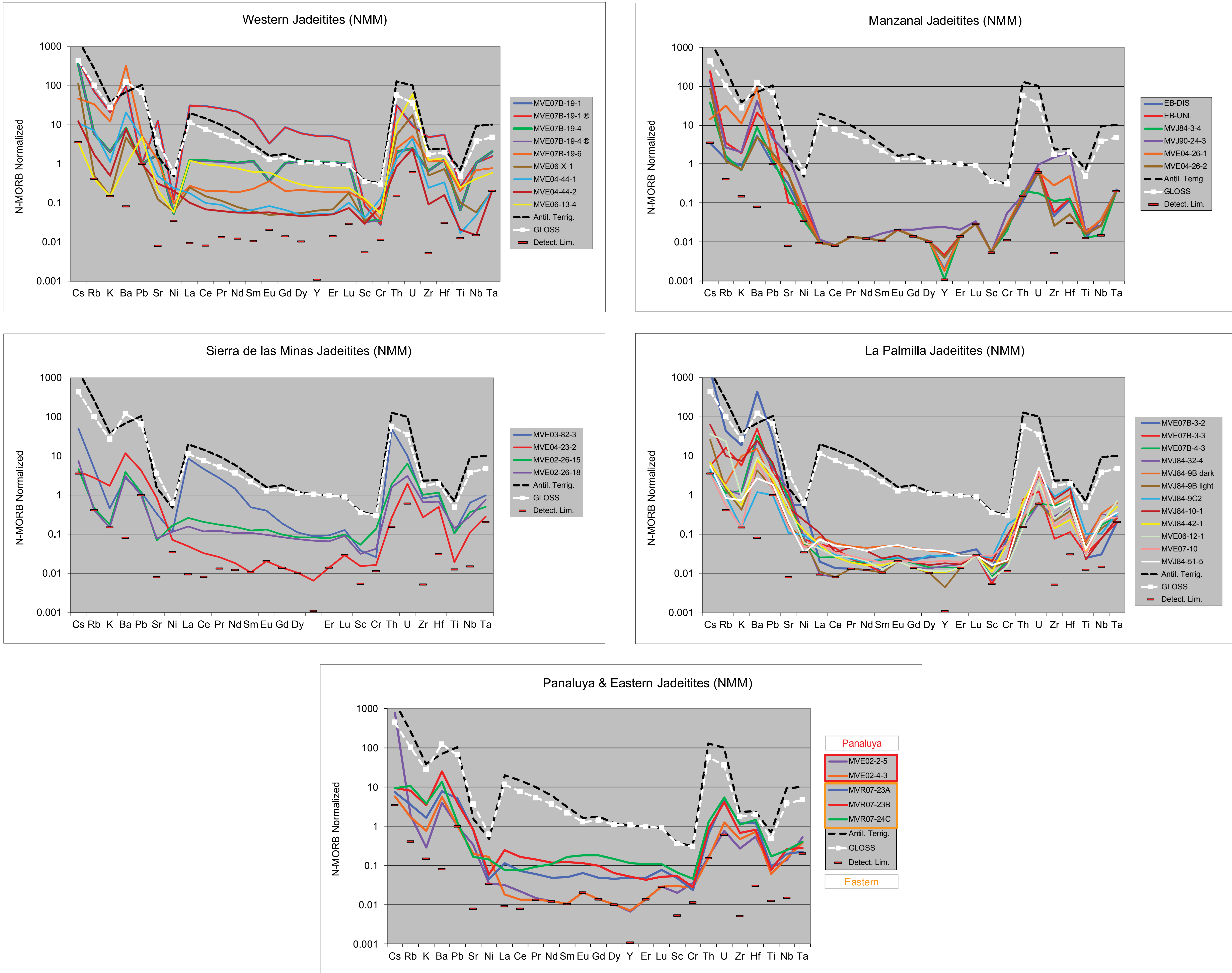

Carrizal Grande \& La Ceiba Jadeitites (SMM)

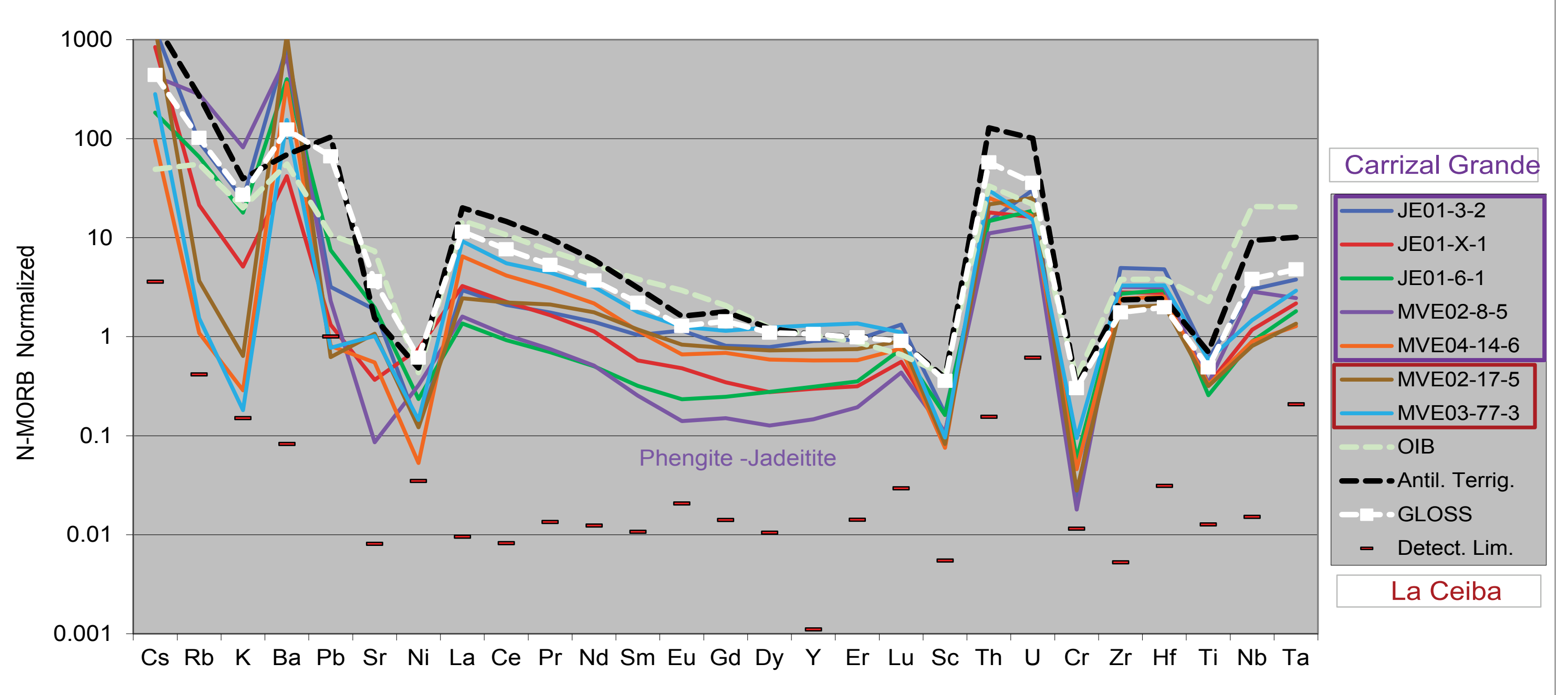

La Ensenada \& El Tambor Jadeitites (SMM)

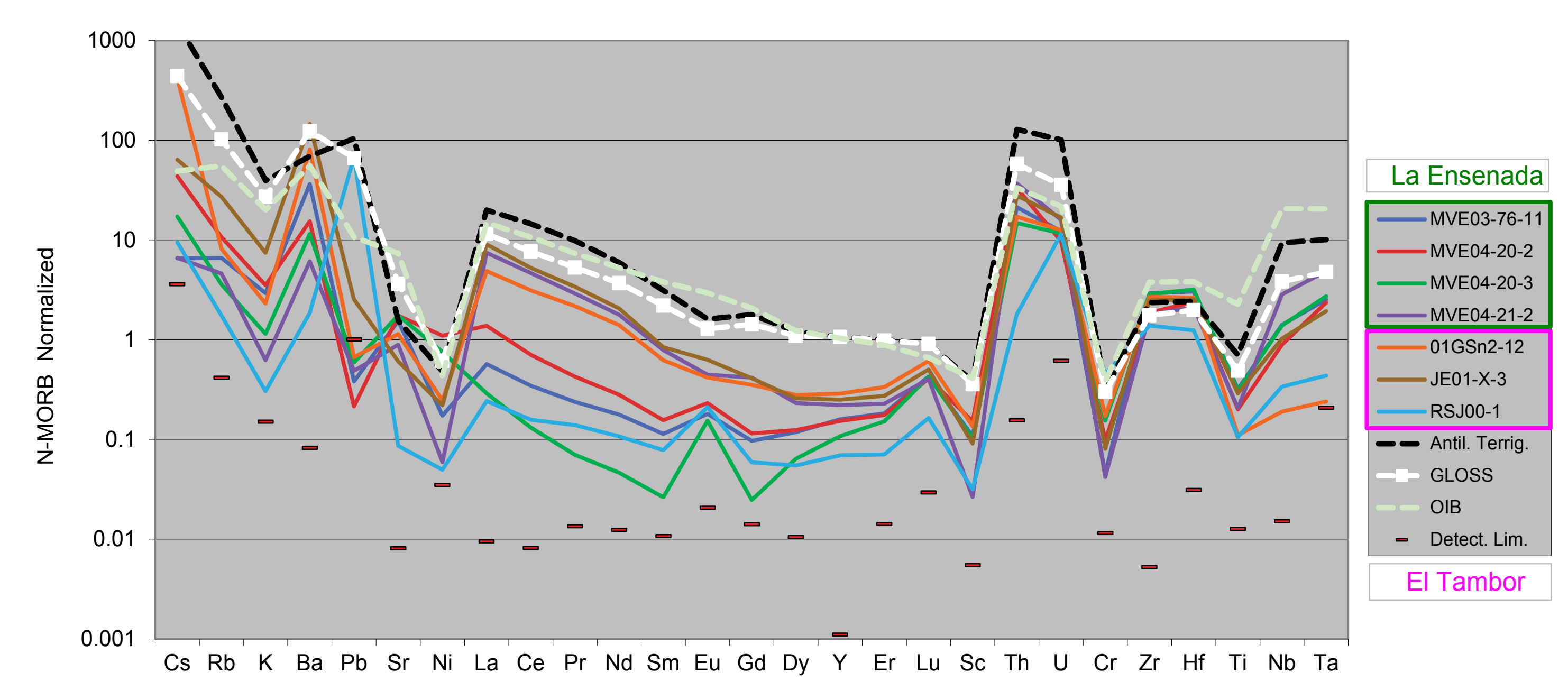




\section{Figure 5}
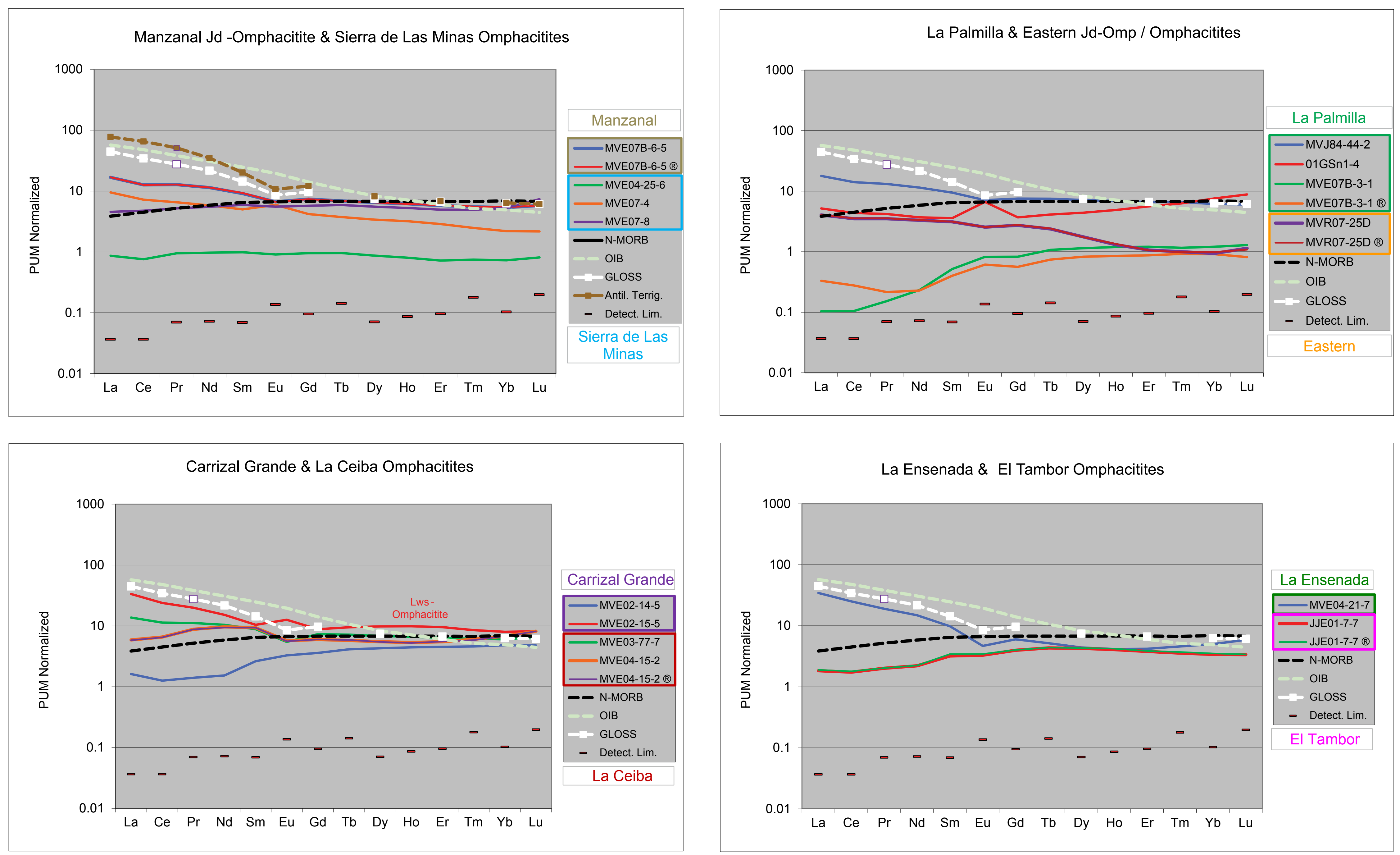
Figure 6
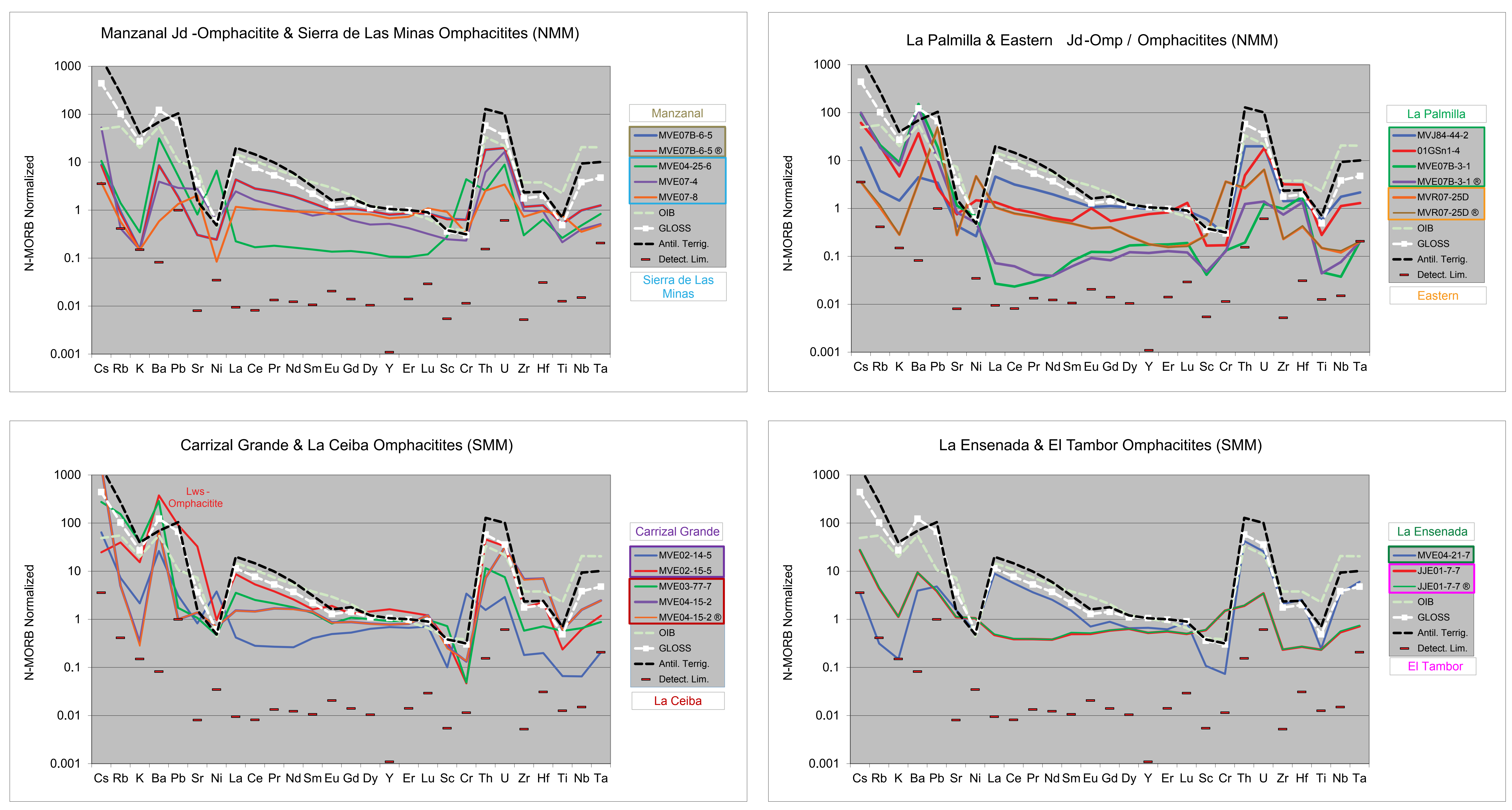


\section{Figure 7}
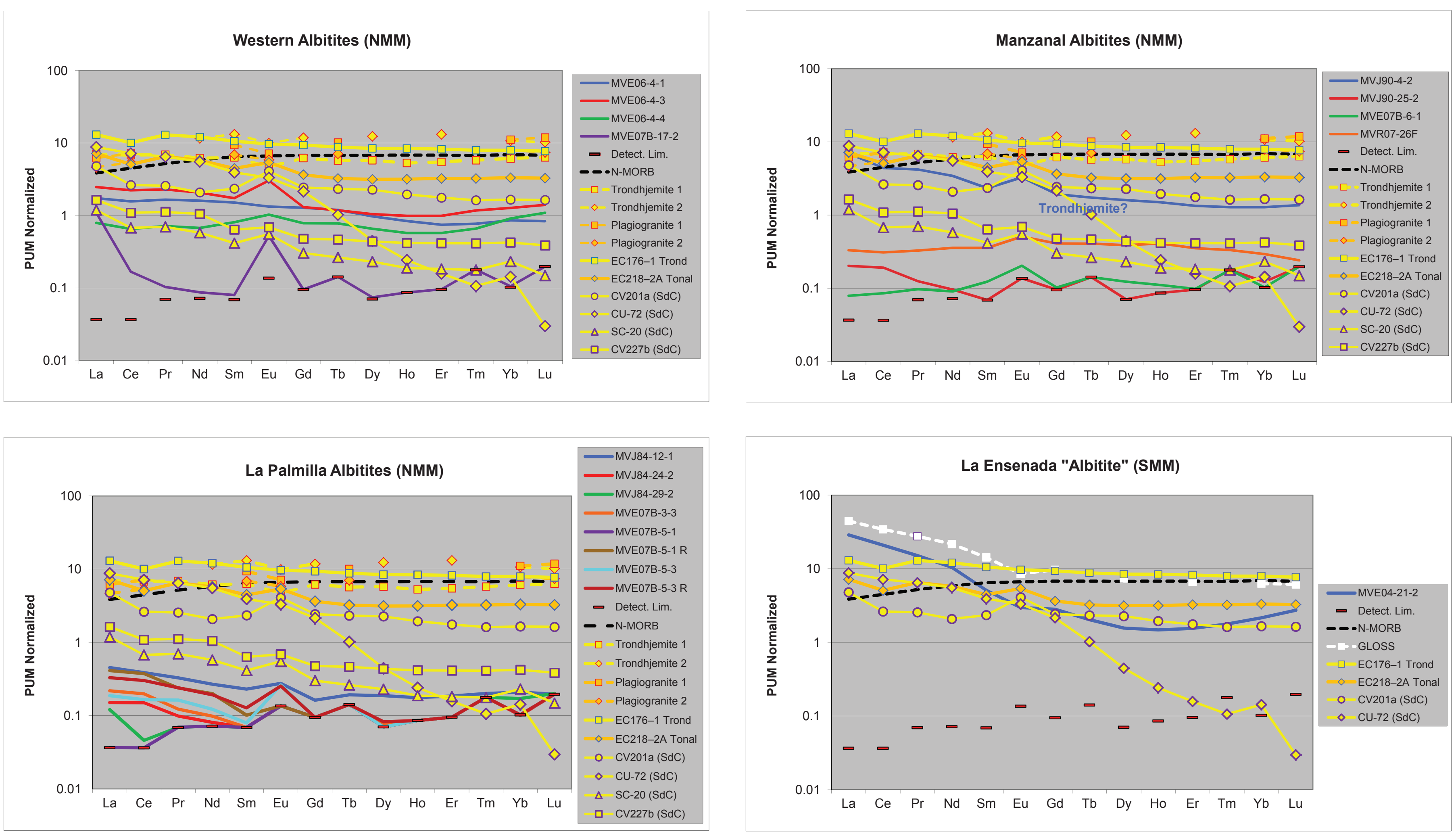
Figure 8
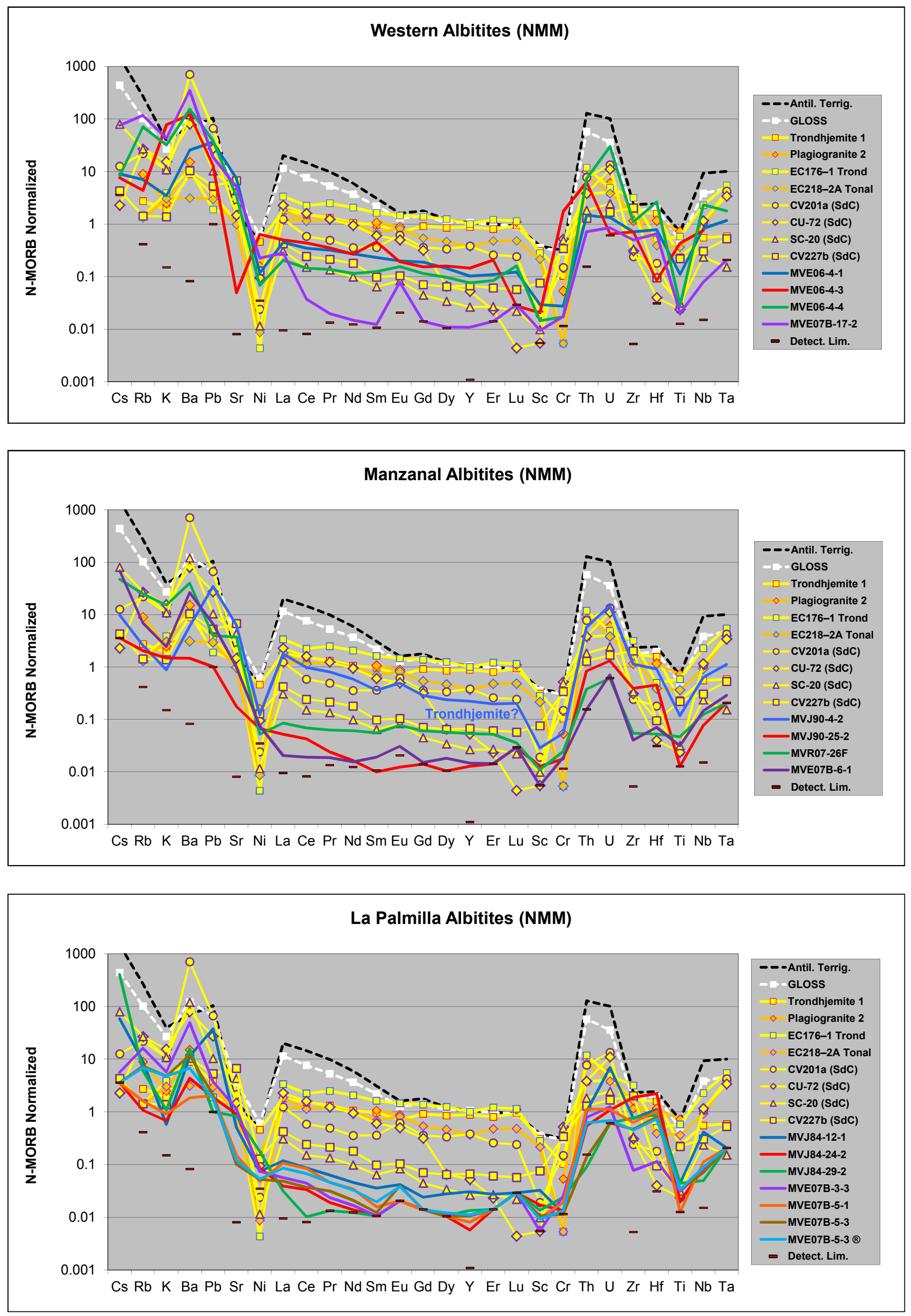


\section{Figure 9}
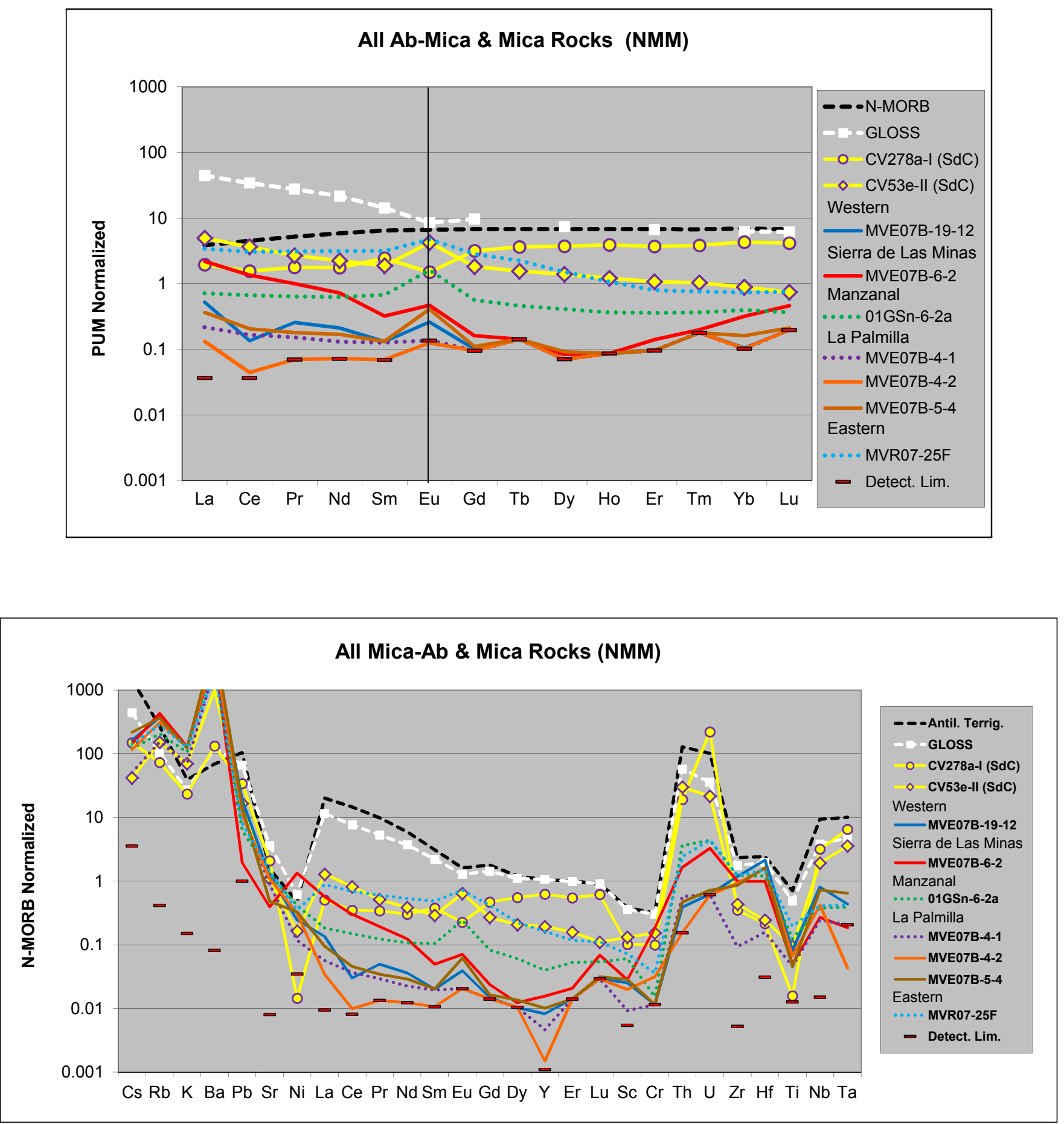

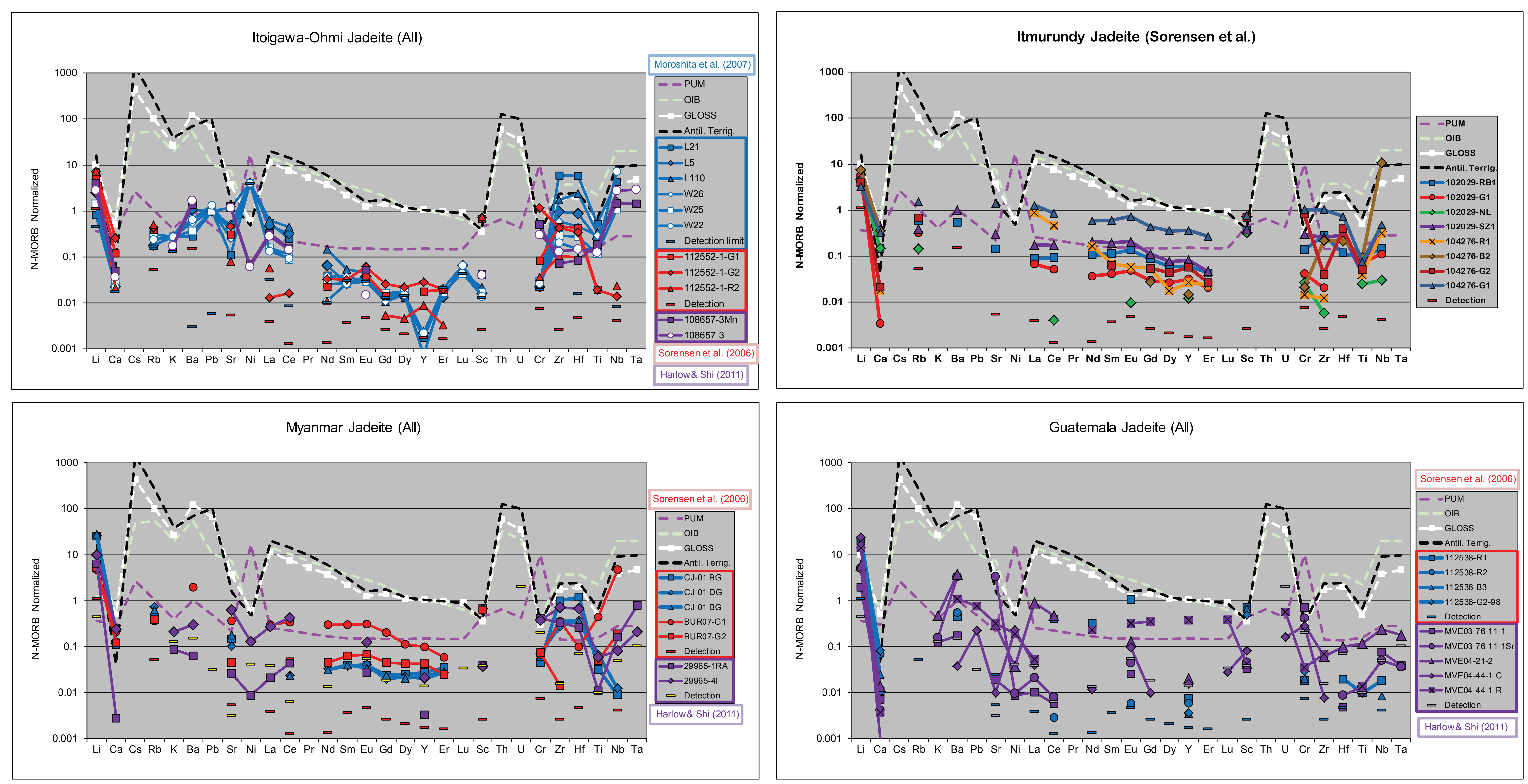


\section{Figure 11}

Jadeitite: Myanmar

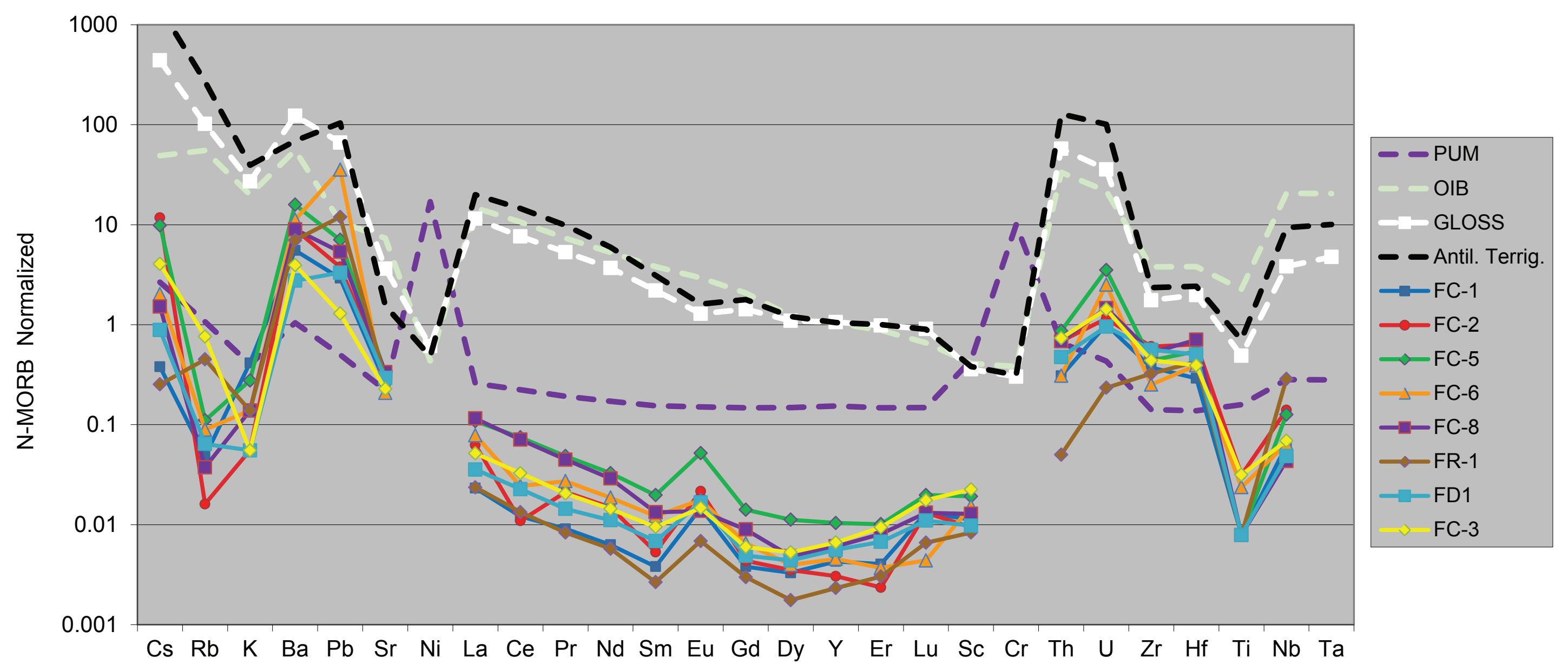

Jadeitite: Syros -Tinos \& Nishisonogi

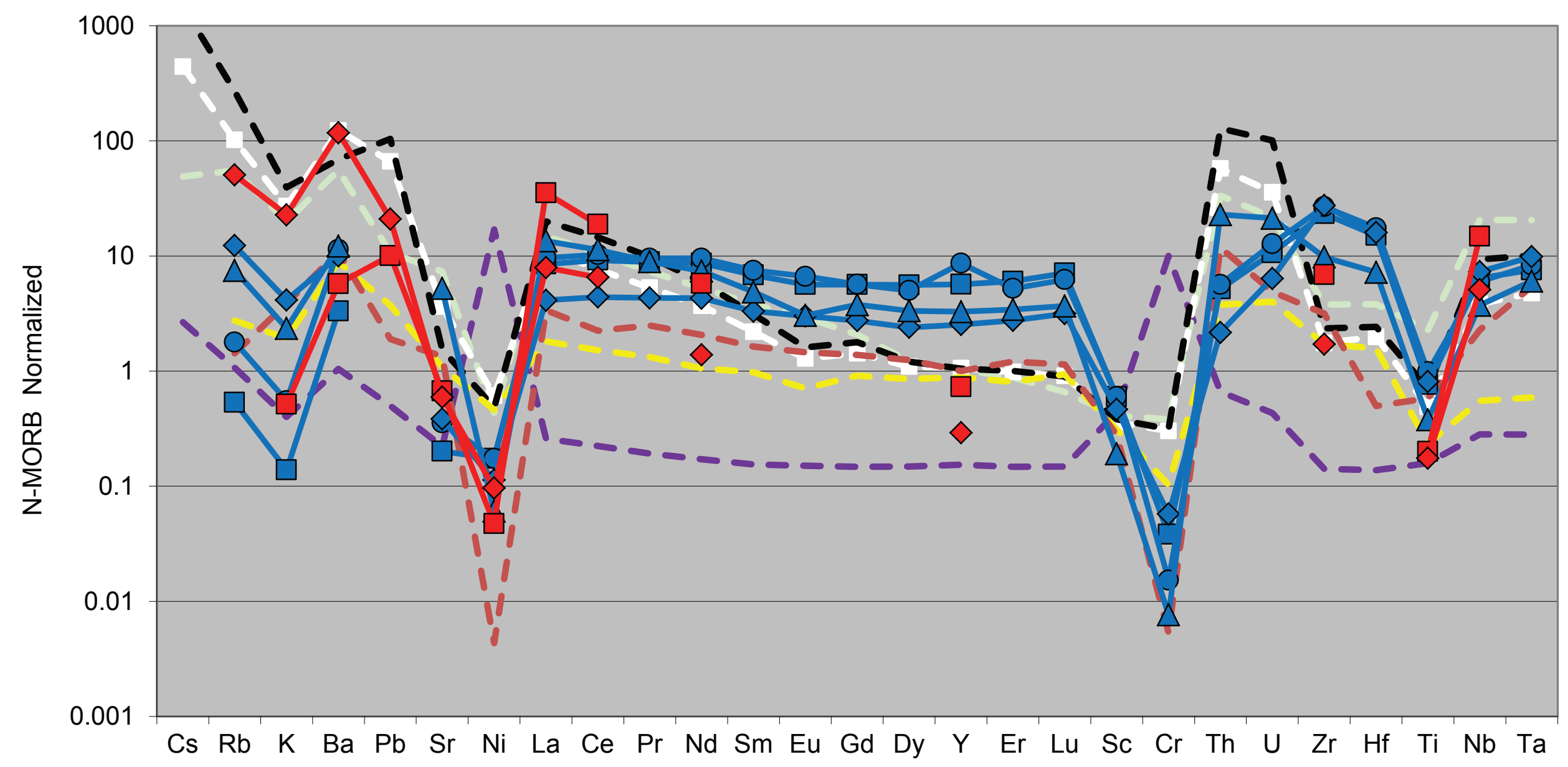

Jadeitite \& Plagiogranite: Western Alps, Italy
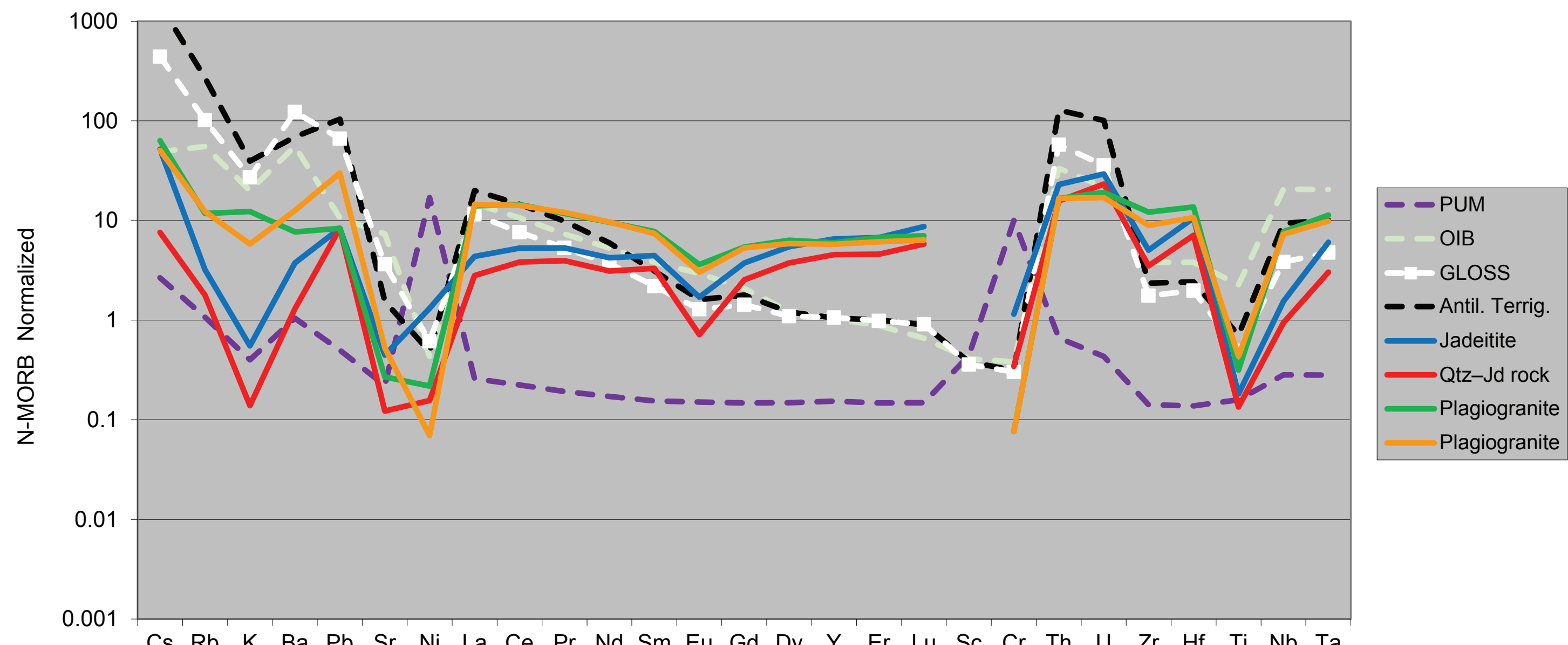
Figure 12

Jadeite-Omphacite \& Omphacite: Itoigawa-Ohmi

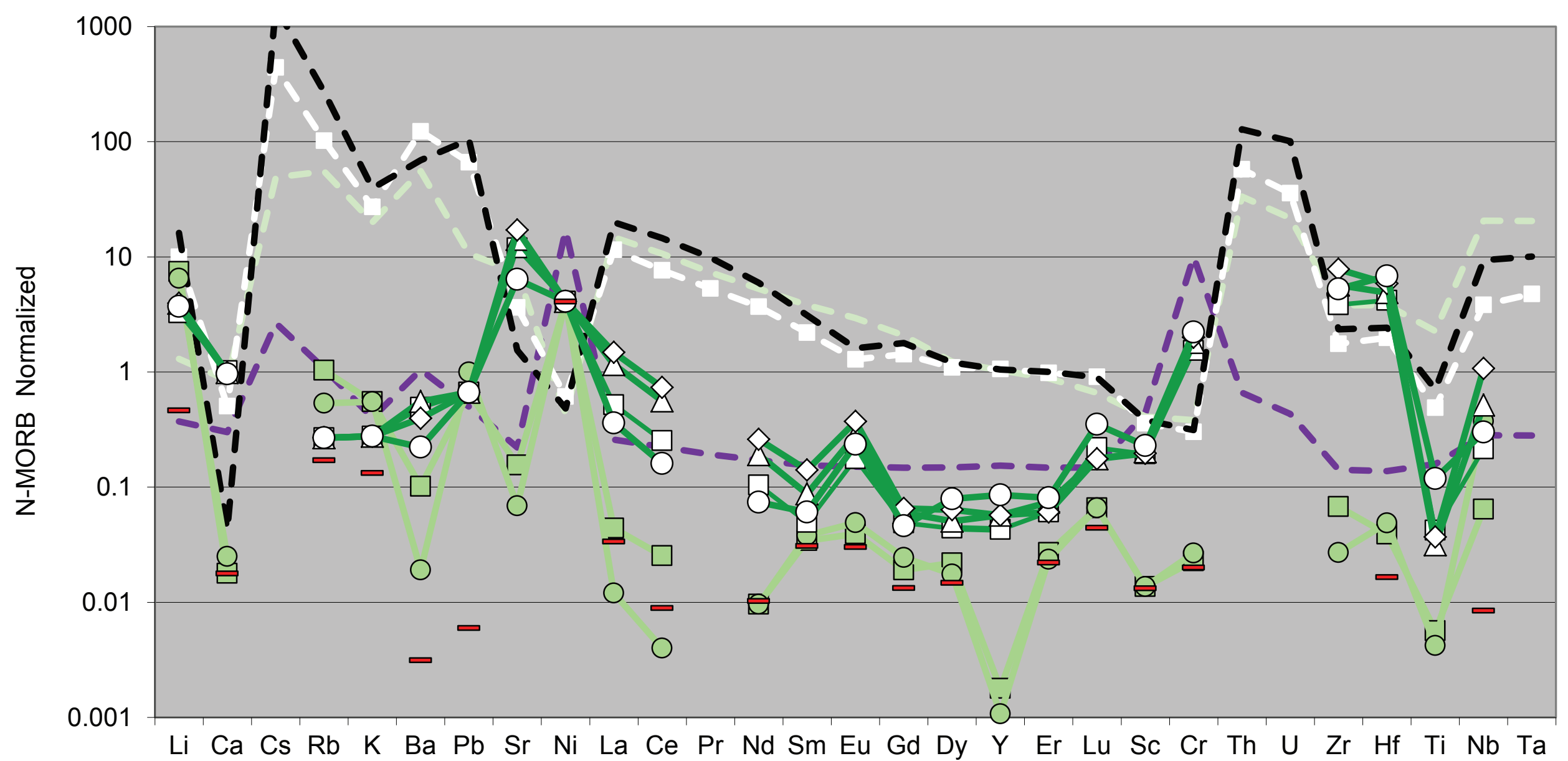

Jadeite

Omphacite

- -PUM

- OIB

GLOSS

- Antil. Terrig.

J8-11

○ J6-26

$-\square-4-40$

$-4-37$

$\rightarrow 4-38$

$-0-4-42$

- Detection limit

Omphacite

Omphacitite: Syros-Tinos \& Nishisonogi

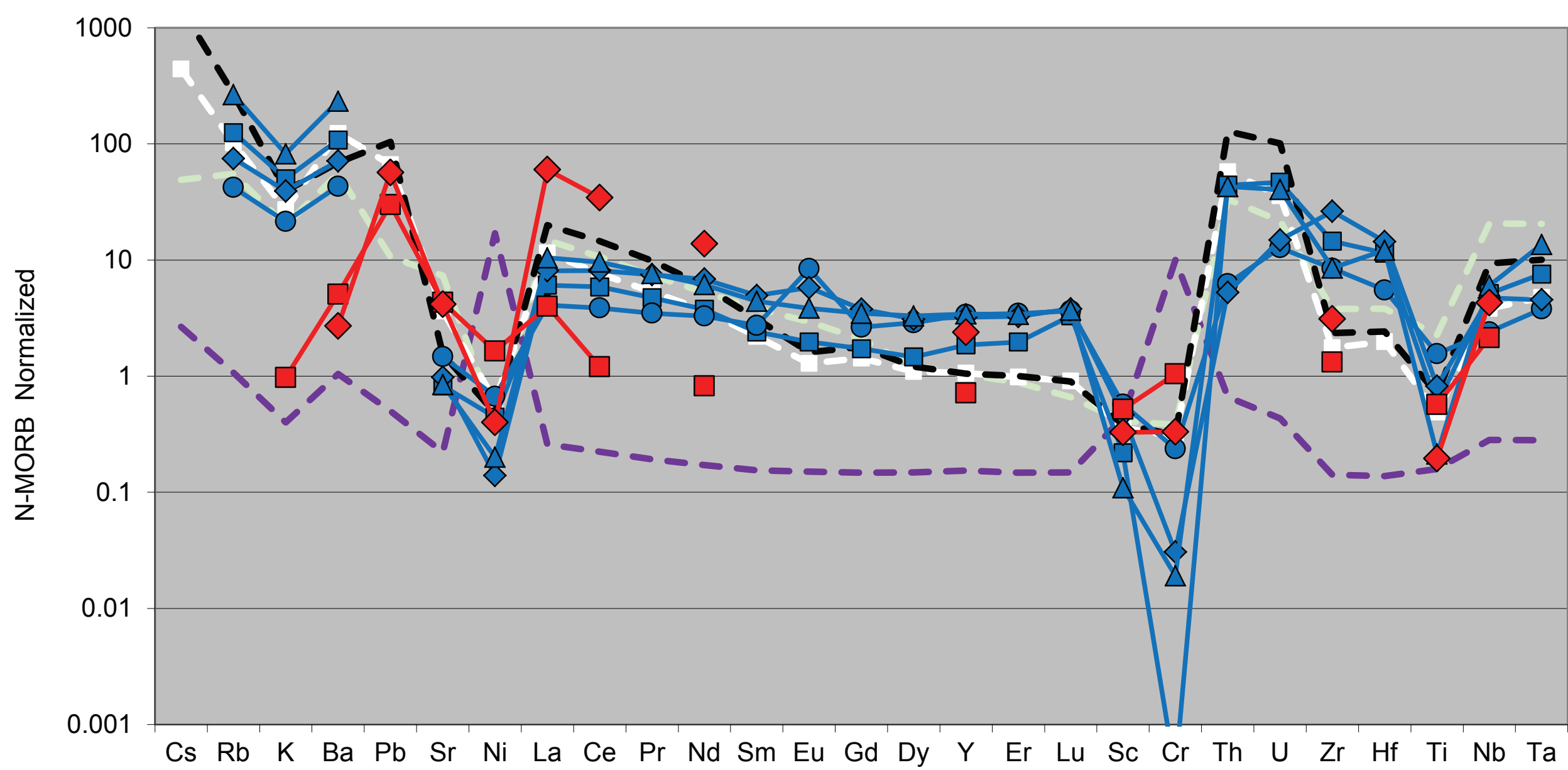

Syros-Tinos

$--\mathrm{PUM}$

$-O$ OIB

GLOSS

- Antil. Terrig.

$-\square-1080$

- -1081

$\checkmark-1083$

$\rightarrow 1085$

$\rightarrow$ OM-Nishi

$\leadsto$ OM-Mie

Nishisonogi 


\begin{tabular}{|c|c|c|c|c|c|c|c|c|c|c|c|c|c|c|c|c|c|c|c|c|}
\hline \multirow{3}{*}{$\begin{array}{l}\text { Table } 1 \\
\text { Sample ID }\end{array}$} & \multirow{2}{*}{ Group } & \multirow{2}{*}{ Description } & \multirow{2}{*}{ Locality } & \multicolumn{4}{|c|}{ Bold IDs have analyses } & \multicolumn{5}{|c|}{ Underlined IDs are by XRD } & \multicolumn{8}{|c|}{ IDs in italics are by optical/petrpgraphic linspection } \\
\hline & & & & $\bar{a}$ & $\stackrel{\bigcirc}{\frac{3}{\partial}}$ & ะ & $\stackrel{\Perp}{\underline{\Xi}}$ & $\underline{\xi}$ & $\stackrel{2}{3}$ & $\stackrel{\varrho}{7}$ & 兽 & $\stackrel{\circ}{\circ} \div$ & $\sum_{\omega}$ & $\stackrel{2}{0}$ & $\Xi$ & $\Xi$ & $\cong$ & $\frac{8}{N}$ & $\stackrel{\varrho}{=}$ & $\stackrel{\circ}{\stackrel{\rho}{\bar{p}}}$ \\
\hline & NMM & & & & & & & & & & & & & & & & & & & \\
\hline MVE07B-19-1 & W Jadeitites & Jadeitite & Q nr. Saltán & $x x x$ & & $\mathbf{x}$ & $\mathbf{x}$ & $\mathrm{ms}, \mathrm{ph}$ & & grs & $\mathbf{x}$ & $\begin{array}{l}\text { Sr-rich, } \\
\text { Aln }\end{array}$ & & $\mathbf{x}$ & & $\mathrm{x}$ & $\mathrm{x}$ & & & $\begin{array}{l}\text { Kfs, mon, } \\
\text { cls }\end{array}$ \\
\hline MVE07B-19-4 & W Jadeitites & Jadeitite & Q nr. Saltán & $x \mathbf{x x}$ & & $x$ & $x$ & $\mathrm{~ms}, \mathrm{ph}$ & & grs & $x$ & $\begin{array}{l}\text { Sr-rich, } \\
\text { Aln }\end{array}$ & & & & $x$ & $\mathrm{x}$ & & & ves, Kfs \\
\hline MVE07B-19-6 & W Jadeitites & Jadeitite & Q nr. Saltán & $\mathbf{x x x}$ & $\mathrm{x}$ & $\mathrm{x}$ & & Ba-ph & & & & $\mathrm{x}$ & & & $?$ & $\mathrm{x}$ & & & $\mathrm{x}$ & \\
\hline MVE06-X-1 & W Jadeitites & Jadeitite & Pachalum & $\mathrm{xx}$ & $\mathbf{x}$ & $\mathbf{x}$ & & prs & trm & & & & & & & $\mathrm{x}$ & $\mathrm{x}$ & & & ne, gph \\
\hline MVE04-44-1 & W Jadeitites & Jadeitite & Q. Los Pescaditos & $\mathrm{xxx}$ & $\mathrm{x}$ & $\mathrm{x}$ & $\mathrm{x}$ & $\mathrm{pg} / \mathrm{ph}$,prs & & & $\mathbf{x}$ & & & & & & & & & bnl,ne \\
\hline MVE04-44-2 & W Jadeitites & Jadeitite & Q. Los Pescaditos & $x \mathbf{x x}$ & $\mathrm{x}$ & $\mathrm{x}$ & $\mathbf{x}$ & $\mathrm{pg}$ & & & & $\mathrm{x}$ & & & & $\mathbf{x}$ & & & & ne \\
\hline MVE06-13-4 & Río Comaja & Jadeitite & Río Comaja & $\mathbf{x x x}$ & $\mathrm{x}$ & $\mathbf{x}$ & $\mathbf{x}$ & & & & & & & & & & & & & \\
\hline EB-DIS & Manzanal & Jadeitite & Manzanal & $x x x$ & & $x$ & $x$ & $x$ & & & & & & & & & & & & gph? \\
\hline EB-UNL & Manzanal & Jadeitite & Manzanal & $x x x$ & $x$ & $x$ & $?$ & & & & & & & & & & & & & ne, gph? \\
\hline MVJ84-3-4 & Manzanal & Jadeitite & Manzanal & $x \mathbf{x x}$ & & $\mathrm{x}$ & $x$ & & & & & & & & & & & & & \\
\hline MVJ90-24-3 & Manzanal & Jadeitite & $\begin{array}{c}\text { Manzanal } \\
\text { btw Manzanal \& Río }\end{array}$ & $x x x$ & $\mathrm{x}$ & & & $\mathrm{pg}$ & & & & $\mathrm{x}$ & & & & & & & & kfs, ba \\
\hline MVE04-26-1 & Manzanal & Ab-Jadeitite & Uyus & $\underline{x x}$ & $x$ & $\underline{\mathrm{x} x}$ & $\underline{x}$ & ph & & & & & & & & & & & & \\
\hline MVE03-82-3 & $\begin{array}{l}\text { Sierra Las } \\
\text { Minas } \\
\text { Sierra Las }\end{array}$ & Jadeitite & $\begin{array}{l}\text { El Mapache } \\
\text { Piedra Parada Dos }\end{array}$ & $x \mathrm{xx}$ & $x$ & $x$ & $\mathbf{x}$ & pg & trm & & & & & & & & & & & \\
\hline MVE04-23-2 & $\begin{array}{l}\text { Minas } \\
\text { Sierra Las }\end{array}$ & Jadeitite & Ríos & $x x$ & $x$ & $x$ & $x$ & $x$ & $\mathrm{trm}$ & & & $z o$ & & & & & $x$ & & & gph \\
\hline MVE02-26-15 & $\begin{array}{l}\text { Minas } \\
\text { Sierra Las }\end{array}$ & Jadeitite & El Ciprés & $x x$ & $x$ & $x$ & & $p g$ & & & & & & & & $x$ & & & & \\
\hline MVE02-26-18 & Minas & Jadeitite & El Ciprés & $x x x$ & $x$ & & $x$ & $p g$ & & & & & & & & $x$ & & & & \\
\hline MVE07B-3-2 & La Palmilla & Jadeitite & Cerro Colorado & $x x x$ & $\mathrm{x}$ & $\mathrm{x}$ & $\mathrm{x}$ & $\mathrm{ph}$ & & & & $\mathrm{cz}$ & & & & & $x$ & & & $\mathrm{hm}$, brt \\
\hline MVE07B-3-3 & La Palmilla & Jadeitite (Albitite) & N. of Cerro Colorado & $x x x$ & & $x$ & $x$ & ph & & & & & & & & & & & & \\
\hline MVE07B-4-3 & La Palmilla & Jadeitite & Cerro Colorado & $x x x$ & & $\mathrm{x}$ & $\mathbf{x}$ & pg/prs/ & & & & czoi & & & & $\mathrm{x}$ & & & & gph \\
\hline MVJ84-32-4 & La Palmilla & Jadeitite & N. of Cerro Colorado & $x x x$ & $x$ & $x$ & & $\mathrm{pg}$ & & & & & & & & & & & & gph \\
\hline dark & La Palmilla & Jadeitite & Río La Palmilla & $x x$ & & $\mathrm{x}$ & $\mathrm{x}$ & & trm & & & $\mathrm{x}$ & & & & & & & & \\
\hline light & La Palmilla & Jadeitite & Río La Palmilla & $x x x$ & & $\mathrm{x}$ & $\mathbf{x}$ & pg,prs & & & & $\mathrm{x}$ & & & & & & & & ne \\
\hline MVJ84-9C2 & La Palmilla & $\begin{array}{l}\text { Jadeitite } \\
\text { Ex-Jadeitite-Ab- }\end{array}$ & Río La Palmilla & $\mathbf{x x x}$ & $\mathrm{x}$ & $\mathrm{x}$ & $x$ & pg,prs & trm & & & $\mathrm{x}$ & & & & $\mathrm{x}$ & & & & \\
\hline MVJ84-10-1 & La Palmilla & Ne symplectite & Río La Palmilla & ? & $x$ & $x x$ & & $x$ & & & & $z o i$ & & & & $?$ & $x$ & & & $n e(x x)$ \\
\hline MVJ84-42-1 & La Palmilla & Jadeitite & Río La Palmilla & $x x$ & & $\mathrm{x}$ & $\mathbf{x}$ & pg,prs & trm & & & $\mathbf{x}$ & & & & $\mathrm{x}$ & & & & ne \\
\hline MVE06-12-1 & La Palmilla & Jadeitite & Río La Palmilla & $x x$ & $x$ & $x$ & $x$ & $p g$ & $\mathrm{trm}$ & & & $z o$ & & & & & & & & gph \\
\hline MVE07-10 & La Palmilla & Jadeitite & Río La Palmilla & $\mathbf{x x x}$ & $\mathrm{x}$ & $\mathrm{x}$ & $x$ & & & & & & & & & & & & & \\
\hline MVJ84-51-5 & La Palmilla & Jadeitite & N. of Q. Escorpión & $x x$ & & $x$ & $x$ & $x$ & & & & zo & & & & $?$ & & & & \\
\hline MVE02-2-5 & Panaluya & Jadeitite & Panaluya & $x x x$ & $\mathrm{x}$ & $\mathbf{x}$ & $\mathrm{x}$ & pg & trm & & & & & $\mathrm{x}$ & & $\mathrm{x}$ & $\mathrm{x}$ & & & bnl \\
\hline MVE02-4-3 & Panaluya & Jadeitite & Panaluya & $x x x$ & $\mathrm{x}$ & $\mathrm{x}$ & $\mathrm{x}$ & $\mathrm{pg} / \mathrm{bio}$ & & & & $\mathrm{x}$ & & & & & & & & \\
\hline MVR07-23A & E. Jadeitites & Jadeitite & Aldea Las Cruces & $x x x$ & & $x$ & & $x$ & & & & & & & & $x$ & $x$ & & & bio \\
\hline MVR07-23B & E. Jadeitites & Jadeitite & Aldea Las Cruces & $x x x$ & & $x$ & & $x$ & & & & & & & & $x$ & $x$ & & & bio \\
\hline MVR07-24C & E. Jadeitites & Jadeitite & Rosario & $x \mathbf{x}$ & $\mathrm{x}$ & $\mathrm{x}$ & $\mathbf{x}$ & $\mathrm{pg} / \mathrm{ph} / \mathrm{phl}$ & & & & & & & & & & & & \\
\hline MVE07B-6-5 & Manzanal & $\begin{array}{l}\text { Mylonitized } \\
\text { Jadeitite- } \\
\text { Omphacitite }\end{array}$ & Uyus-Manzanal & $x x$ & aeg? & $x$ & & & trm & & & & & & & $x$ & $x$ & & trace & py \\
\hline MVE07B-3-1 & La Palmilla & Jadeitite- & Cerro Colorado & $\mathbf{x x}$ & $x x$ & $\mathrm{x}$ & & $\mathrm{phl} / \mathrm{ph} / \mathrm{pg}$ & & & & $\mathrm{cz}$ & & & & & $x$ & & & $\mathrm{hm}$, brt \\
\hline
\end{tabular}

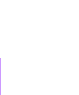

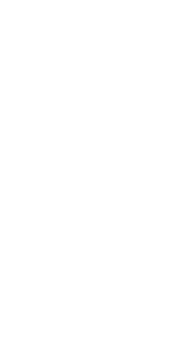

(1)




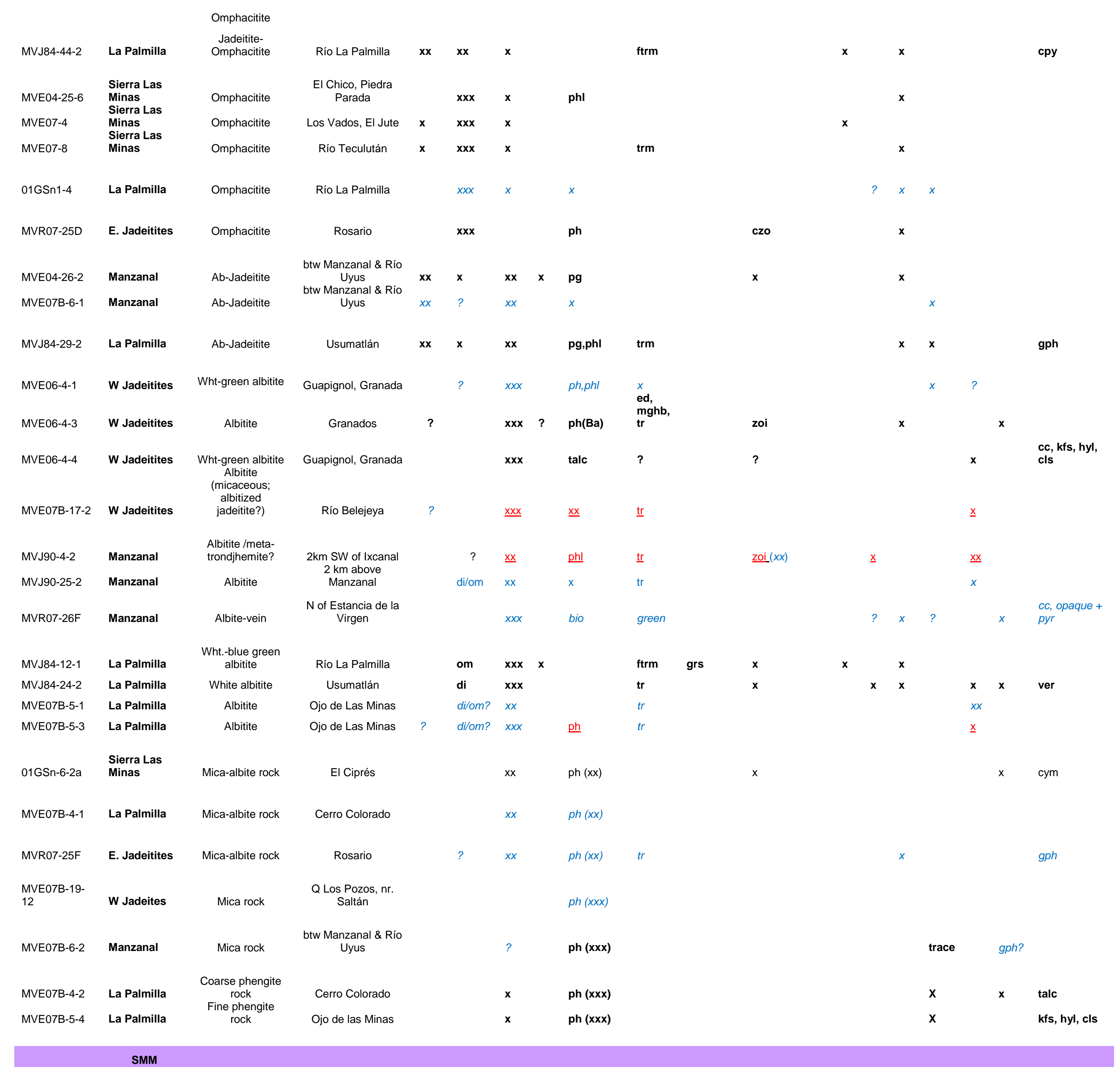




\begin{tabular}{|c|c|c|c|c|c|c|c|c|c|c|c|c|c|c|c|c|c|c|c|c|}
\hline JE01-3-2 & $\begin{array}{l}\text { Carrizal } \\
\text { Grande } \\
\text { Carrizal }\end{array}$ & Jadeitite & Q. El Silencio & $x \mathrm{xx}$ & $\mathrm{x}$ & $\mathrm{x}$ & & $\mathrm{ph}(\mathrm{xx})$,bio & & & & & & & & $\mathrm{x}$ & $\mathrm{x}$ & & $\mathrm{x}$ & \\
\hline JE01-X-1 & $\begin{array}{l}\text { Grande } \\
\text { Carrizal }\end{array}$ & $\begin{array}{l}\text { Jadeitite } \\
\text { Jadeitite- }\end{array}$ & Q. El Silencio & $\underline{x x x}$ & & & $\underline{x}$ & ph & & & & $\underline{\text { aln }}$ & & & & $\underline{x}$ & & & & \\
\hline JE01-6-1 & $\begin{array}{l}\text { Grande } \\
\text { Carrizal }\end{array}$ & Omphacitite & Río La Puerta & $\mathbf{x x}$ & $x x$ & & & $\mathrm{ph}(\mathrm{xx})$ & & & & ? & $\mathrm{x}$ & & $\mathbf{x}$ & $\mathrm{x}$ & $\mathrm{x}$ & & & \\
\hline MVE04-14-6 & Grande & Jadeitite & Q. Seca & $\mathbf{x x x}$ & $\mathrm{x}$ & $\mathrm{x}$ & $\mathrm{x}$ & $\mathrm{ph}$ & & & & & & & & $\mathrm{x}$ & $\mathbf{x}$ & $\mathrm{x}$ & & cym, \\
\hline RSJ00-1 & El Tambor & Jadeitite & Río Jalapa & $\mathbf{x x x}$ & $\mathrm{x}$ & $x$ & & ph & & & & & & & & $\mathrm{x}$ & & & & \\
\hline JE01-X-3 & El Tambor & Jadeitite & Río El Tambor & $x \mathbf{x x}$ & $\mathrm{x}$ & $\mathrm{x}$ & $\mathrm{x}$ & Ba-ph & gln & & & & $\mathrm{x}$ & $\mathrm{x}$ & $\mathbf{x}$ & $\mathrm{x}$ & $\mathrm{x}$ & $\mathbf{x}$ & & \\
\hline 01GSn2-12 & El Tambor & Jadeitite & Río El Tambor & $x x x$ & $x$ & $?$ & & $p h$ & & & & & ? & & & & $x$ & & & \\
\hline MVE02-17-5 & La Ceiba & $\begin{array}{l}\text { Jadeitite } \\
\text { Dark green }\end{array}$ & La Ceiba & $\mathbf{x x x}$ & $\mathrm{x}$ & & $\mathrm{x}$ & & & & & & & & & $\mathrm{x}$ & $\mathrm{x}$ & $\mathbf{x}$ & & cym,ves \\
\hline MVE03-77-3 & La Ceiba & Jadeitite & La Ceiba & $\mathbf{x x x}$ & $\mathrm{x}$ & $x$ & & $\mathrm{ph}$ & & & & & & & & $\mathrm{x}$ & $\mathrm{x}$ & & $\mathrm{x}$ & cls,kfs \\
\hline MVE03-76-11 & La Ensenada & Pmp-Jadeitite & Qbda La Peña & $x x$ & & $x$ & & ph & & & $x$ & & & & & $x$ & $x$ & & & \\
\hline MVE04-20-2 & La Ensenada & Pmp-Jadeitite & Qbda La Peña & $x x$ & & $x$ & & ? & & & $x x$ & & & & $x$ & $x$ & $x$ & & $x$ & \\
\hline MVE04-20-3 & La Ensenada & Pmp-Jadeitite & Qbda La Peña & $x \mathbf{x}$ & & $\mathrm{x}$ & & $\mathrm{ph}$ & & grs & $\mathbf{x x}$ & ? & & & $\mathbf{x}$ & $\mathrm{x}$ & $\mathrm{x}$ & & & \\
\hline MVE04-21-2 & La Ensenada & Albite-Jadeitite & E of San Diego Rd & $x x$ & & $x x$ & & $p h$ & & grs & & & & & & $x$ & & $x$ & & \\
\hline MVE02-14-5 & $\begin{array}{l}\text { Carrizal } \\
\text { Grande }\end{array}$ & Gln-Omphacitite & Q. del Mico & & $\mathbf{x x}$ & $\mathbf{x}$ & & & $\underset{t r}{\operatorname{gln}(x x)}$ & & & & & & & & & & & \\
\hline JJE01-7-7 & El Tambor & $\begin{array}{l}\text { Omphacitite } \\
\text { Omphacitite w/ }\end{array}$ & Río El Tambor & & $\underline{\mathrm{xx} x}$ & $\underline{x}$ & & & $\mathrm{gln}, \mathrm{tr}$ & & & & ? & & ? & $\underline{x}$ & ? & $\mathrm{x}$ & & $\underline{c p y}$ \\
\hline MVE04-21-7 & La Ensenada & $A b+G r s+Q t z$ & E of San Diego Rd & $x$ & $x x, d i$ & $x$ & & & & grs & ? & & & & & $x$ & & $\mathrm{x}$ & & \\
\hline MVE03-77-7 & La Ceiba & Omphacitite & La Ceiba & & $x x$ & & & $p h(x x)$ & $g / n$ & & & & & & & $x$ & & & & \\
\hline MVE04-15-2 & La Ceiba & Gln-Omphacitite & La Ceiba & ? & $x x$ & $x$ & ? & & $g \ln (x x)$ & & & & & & & $x$ & $x$ & & & $c c ?$ \\
\hline MVE02-15-5 & $\begin{array}{l}\text { Carrizal } \\
\text { Grande }\end{array}$ & Lws-Omphacitite & Q. Seca & & $x x$ & & & & & & & & $x x$ & & $\mathrm{x}$ & $x$ & $\mathrm{x}$ & & $x$ & Ba-kfs \\
\hline MVE06-17-2 & $\begin{array}{l}\text { Carrizal } \\
\text { Grande }\end{array}$ & $\begin{array}{c}\text { Grt-Ab-Qtz- } \\
\text { Jadeitite }\end{array}$ & Q. del Mico & $x x$ & $x$ & $\mathrm{x}$ & & ph & $g \ln ?$ & $\mathrm{alm}$ & & ep & $x$ & $x$ & $\mathbf{x}$ & $x$ & $\mathrm{x}$ & $\mathrm{x}$ & & gph \\
\hline MVE02-15-6 & $\begin{array}{l}\text { Grande } \\
\text { Carrizal }\end{array}$ & Ab-Qtz-Jadeitite & Q. Seca & $\mathbf{x x}$ & $\mathrm{x}$ & $\mathbf{x}$ & & $\mathrm{ph}$ & & & & & & & & $\mathrm{x}$ & $\mathbf{x}$ & $\mathbf{x}$ & & kfs \\
\hline MVE02-15-9 & Grande & Ab-Qtz-Jadeitite & Q. Seca & $x x$ & ? & $x x$ & & $x$ & & & & & & & ? & $x$ & & & & \\
\hline MVE02-15-10 & Grande & Ab-Qtz-Jadeitite & Q. Seca & $x \mathbf{x}$ & $\mathrm{x}, \mathrm{Di}$ & $\mathrm{x}$ & & ph & $\operatorname{tr}$ & & & $?$ & & $\mathrm{x}$ & & $\mathrm{x}$ & $\mathrm{x}$ & $\mathbf{x}$ & & \\
\hline MVE02-8-5 & $\begin{array}{l}\text { Carrizal } \\
\text { Grande }\end{array}$ & Pheng-Jadeitite & Q. El Silencio & $x x$ & $\mathbf{x}$ & & & $\mathrm{ph}(\mathbf{x x})$ & & & & & & & $x$ & $x$ & $x$ & $x$ & & \\
\hline
\end{tabular}

Abbreviations after Whitney and Evans (2010), except bnl = banalsite, cym = cymrite, ftrm = ferrotaramite, hyl = hyalophane, prs = preiswerkite, and wm = white
mica 